\title{
Turizm, Terörizm ve Siyasi İstikrarsızlık ${ }^{1}$
}

Tourism, Terrorism, and Political Instability

\author{
Sevil F. SÖNMEZ* \\ * Arizona State University, ABD
}

Türkçeye çevirenler:

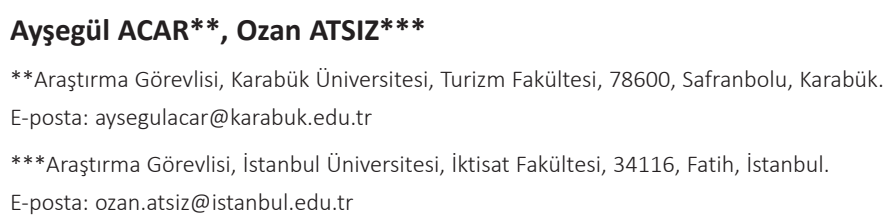

MAKALE BILGILERI

Anahtar sözcükler: Terörizm, Siyasi istikrarsızlık, Savaş, Uluslararası turizm, Tatil yeri imajı, Kriz yönetimi, Pazar iyileştirme.

\section{ARTICLE INFO}

Key words: Terrorism, Political instability, War, International tourism, Destination image, Crisis management, Recovery marketing.

\section{öz}

Terörizm, siyasi kargaşa ve savaş kavramları, turizmle alakasız görünse de bu olguların kesişme noktalarının ve turizme etkilerinin yakından incelenmesi, böyle olmadığını göstermektedir. Bu makale, bu olgular arasındaki ilişkileri irdeleyen alanyazın üzerinde durmaktadır Mevcut çalışmalardan elde edilen araştırma konuları, terörizm ve siyasi istikrarsızlığın turistik talep üzerindeki etkilerini, teröristlerin turistleri hedef alma sebeplerini, turizmin siyasi bir araç olarak kullanılmasını, siyasi şiddetin destinasyon imajı üzerindeki etkilerini, kriz yönetimini ve pazarı iyileștirme çabalarını içermektedir. Bu makalenin amacı, bu ilișkiler üzerine bir sentez oluşturmak, ilgili yayınların kapsamlı bir listesini sunmak ve sonraki araştırmalar için başıklar önermektir

\section{ABSTRACT}

Concepts of terrorism, political turmoil, and war appear unrelated to tourism. Closer examination of their points of convergence and impacts on tourism reveals otherwise. This paper examines literature focusing on the relationships between these phenomena. Research themes which emerge from available studies include impacts of terrorism and political instability on tourist demand, motives of terrorists in targeting tourists, using tourism as a political tool, the effects of political violence on destination image, crisis management, and recovery marketing efforts. The intent of this article is to synthesize research on these relationships, to present a comprehensive index of relevant publications, and to suggest topics for future research.

\section{GiRiş}

Göstermiş olduğu ekonomik başarı bile uluslararası turizmi, terörizmin tehditkâr gücünden koruyamamaktadır. Doğa ve insan kaynaklı birçok felaket, turizmin akışını büyük ölçüde etkileyebilirken, terörizm ve siyasi kargaşa ile gelen tehdit, potansiyel turistlerin daha fazla korkmasina yol açmaktadır. Muhtemel terörizm şiddeti ve kor-

\footnotetext{
${ }^{1}$ Sonmez, S.F. (1998) tarafından yazılan "Tourism, terrorism, and political instability, Annals of Tourism Research, 25(2): 416456" künyesini taşıyan makaleden dergi yayıncısının izni alınarak çevrilmiştir.
}

kusu yeni bir şey değildir fakat bilim insanlarının ilgisini çekmesi ancak 10 yıl kadar öncesine dayanmaktadır. Uluslararası terörizmin 1980'lerin ortasında zirveye çıkması nedeniyle, terörizmin turizm üzerindeki kaçınılmaz etkileri ciddiye alınmaya başlanmıştır. Sonrasında, yaşanan 1991 İran Körfez Savaşı ve bununla bağlantılı olarak küresel terörizmin ortaya çıkma olasılığı, dikkatleri tekrar bu konuya yoğunlaştırmıştır. Tüm dünyada manşetlere taşınan terör olayları ve siyasi kargaşalar sonucunda konuya gösterilen ilgi daha da yoğunlaşmış ve hatta turistleri tehdit 
eden değişken siyasi durumların artışı ile konuyla alakalı basılı eserlerin artışı arasında bir paralellik olduğu da söylenebilir.

Turistlerin güvenliği ve risk konuları, ciddi olduğu kadar aynı zamanda dikkat çekici konulardır. Turizm, terörizm ve siyasi çatışma arasındaki ilişkiye gösterilen ilgi bakımından zengin olan alanyazın, savaş ve suç konuları hakkında da ayrıca araştırmalar sunmaktadır. Ancak, tüm bu araştırmaların uluslararası turizmin, terörizm veya siyasi çatışmalardan nasıl korunacağına dair yeteri kadar bilgi sunup sunmadığı sorusu cevapsız kalmıştır. Terörizm ve turizm alanyazınının birkaç odak noktası vardır: teröristlerin turistleri veya turizm sektörünü hedef alma sebepleri, terörizmin turistik talep üzerindeki etkileri ve riskleri en aza indirmek konusunda turistlere yardımcı olabilecek muhtemel çözüm önerileri. Siyasi kargaşa veya savaşın turizm sektörü üzerindeki etkilerini inceleyen çalışmalar, Filipinler, Fiji, Zimbabve, Zambiya, Tibet, Çin, Meksika ve Yugoslavya gibi belli başlı örnekler üzerinde durmaktadır. Yapılan bu çalışmalar, sözü geçen ülkelerdeki durumları analiz etme ve ülke yönetimlerinin başarılı/başarısız kriz yönetimi girişimlerini inceleme imkânı sağlayan vaka incelemeleri olmaları açısından değer taşımaktadır. Bu vakaların bazıları, farklı bakış açıları kullanılarak incelenmiş ve siyasi bir araç olarak turizm, siyasi kargaşanın turizm üzerindeki etkileri ve piyasayı iyileştirme çabaları gibi daha geniş tartışma başlıkları altında gruplandırılabilirler. Fakat bu vakaların her biri emsalsiz olduğundan, belirli ortak başlıklar altında toplanmaları zor olmaktadır.

Turizm sektörünü de içine alan terörizm ve siyasi kargaşanın iyi bilinen örnekleri ile alakalı çalışmalar -ki bunlar arasındaki ilişkileri gösterme konusunda faydalı olanlar mevcuttur-, sinırlı çözüm önerileri sunabilmektedirler. Siyasi problemlerle zor duruma düşen turistik destinasyonlar bu olumsuz imajla nasıl baş edebilir? ,Turizm sektörü, terörizm veya siyasi anlaşmazlık krizlerini nasıl yönetebilir?, Turizm sektörü, terörizm ve siyasi problemlerin etkilerine karşı nasıl bağışıklık kazanabilir? gibi bazı sorular çalışmalarda cevaplanamamaktadır. Böylelikle, bu çalışma, terörizm, siyasi istikrarsızlık ve turizm arasındaki ilişkiler hakkında bilinenleri birleştirmeyi, gelecekteki çalışmalar için konuyla ilgili mevcut yayınların kapsamlı bir listesini sunmayı ve konu önererek bu tehlikeli ilişkiyi daha iyi anlama ihtiyacını vurgulamayı amaçlamaktadır.

\section{TERÖRIZM VE SIYASI KARGAŞA}

ABD Dışişleri Bakanlığı (1996), terörizmi “ulusal alt gruplar tarafından, sivillerin ve silahsız güvenlik güçlerinin hedef alındığı, önceden planlanmış ve genellikle belirli bir kitleyi etkileme amacında olan, siyasi sebeplere dayalı şiddet", uluslararası terörizmi ise "birden fazla ülkenin topraklarını veya vatandaşlarını kapsayan şiddet" olarak tanımlamaktadır. Terörizm, bir siyasi ifade biçimi olarak, Zealos adı altında teşkilatlanan ve Romalıları Filistin'den atmak için bir terör kampanyası başlatan Yahudi vatanseverlerin Filisten'de Roma hükmüne karşı geldiği 6. yüzyıla dayanmaktadır (Poland 1988; Schlagheck 1988). Bu terim, Fransız hükümetinin düşmanlarını korkutmak ve mağlup etmek için sistematik terörü kullandığ 1792-1794 Fransız İhtilali sonrasında Edmund Burke' in "terör saltanatı"nı eleştirdiği 18. yüzyıla kadar resmi olarak siyasi alanyazında yer almamıştır (Poland 1988; Schlagheck 1988; Murphy 1989). Düzensiz aralıklarla terör kavramı kullanımı günümüze kadar ulaşabilmiştir. Uluslararası terörizm, 1960'ların sonu ve 1970'lerin başında hızlı bir artış göstermiş, kısa bir sessizlik göstermesinin ardından 1980'ler terör şiddeti ile başlamış ve 80 'lerin sonuna gelindiğinde ise terörizm olağan bir hale gelmiştir (D'Amore ve Anuza 1986; Richter ve Waugh 1986). 1990'ların ilk yarısında nispeten daha az terör olayı kaydedilmiş olsa da bu olayların doğası ve boyutu, geçmiş yıllardaki olayların doğası be boyutundan daha büyüktür. ABD Dışişleri Bakanlığı (1997) tarafından son zamanlarda uluslararası terör saldırıları sebebiyle meydana gelen en yüksek ölüm sayısı 311 kişi olarak belirtilmiştir. Terörizmin değişken doğası; terör örgütleri ve istatistikleri hakkında bilgi sunan ve ABD D1şişleri Bakanlığı (1996)'nın yıllık yayınladığı Patterns of Global Terrorism'den bir alıntıyla açıklanmiştır:

1995'e kadar, çoğu ülkede uluslararası terörizm düşüş göstermekteydi ve geçen yıl, bir önceki yıla göre 
ölümle sonuçlanan terör saldırıları sayısı daha azdı. Ne var ki 1995'te uluslararası terörist saldırılarının toplam sayısı 322'den 440'a yükseldi. ABD aleyhine yapılan terör saldırılar 1994 yılında 66 iken 1995 yılında 99'a yükseldi ve katledilen Amerikan vatandaşı sayısı 4'ten 12'ye çıktı. Tüm dünyadaki uluslararası terör saldırılarının bilançosu 1994 yılında 314 iken 1995 'te 165 'e düştü, ancak yaralanan insan sayısı 10 kat artarak 6.291 oldu; sadece 5500 kişi Mart ayında Tokyo metro hattındaki kimyasal saldırıda yaralandı.

Terörizmin, altında yatan sebepleri daha iyi anlayabilmek amacıyla yakından incelenmesi, dünya şartlarının da tahlilini beraberinde gerektirmektedir. Yeni bir milenyum başlamak üzereyken milletler; ilerleyen y1llarda dünya nüfusunun artışında ki endişe verici hız ile alevlenecek olan ve terörizmin gelişmesini besleyen unsurlar olan açlık, hastalık ve sayısız diğer sosyoekonomik ve çevresel problemlerle boğuşmaya başlayacaklardır. Bu durum ise, terör örgütlerinin az gelişmiş ülkelerde zor şartlar altında yaşayan insanlara daha iyi şartlar sunarak yeni üyeler toplayabileceğini tekrar gözler önüne serecektir (D'Amora ve Anuza 1986).

Terörizmi anlayabilmek ve açıklayabilmek için birçok tanım, tipoloji ve teori geliştirilmiştir. Fakat sonuç olarak bütüncül bir teori bulmak zor olmuştur. Neyse ki içlerinden bir açıklama diğer açıklamalara ışık tutmaktadır. Karber'e (1971) göre sembolik bir hareket olarak terörizm, diğer iletişim araçlarına benzer bir şekilde analiz edilebilir. Bu kavramsallaştırma, iletişimin dört temel içeriğinin terörizm bağlamında açıklanmasıyla mümkün olmaktadır: mesajı ileten (terörist), mesajın alıcısı (terörist eyleminin hedefi), mesaj (bireysel veya kurumsal mağdurları içeren terör eylemi) ve geri bildirim (alıcının tepkisi). Karber (1971) tarafından yapılan terörizm tanımı, son 20 yılda dünya çapında gerçekleştirilen terör saldırıları göz önüne alındığında yapılan en gerçekçi terörizm tanımdır. Kitle iletişim araçlarının da yardımıyla teröristler, başka türlü asla ulaşamayacakları geniş kitlelere vaatlerini ve amaçlarını başarılı bir şekilde ulaştırabilmektedirler.

Terörizmin geleceğine yönelik birbirlerini destekleyen kaynaklar tarafından yapılan tahminler, terör örgütlerinin daha sık ve cesur eylemler yapacağını ön görmektedir ( $\mathrm{D}^{\prime}$ Amore ve Anuza 1986; Jenkins 1987, 1988; ABD Dişişleri Bakanlığ 1996). Uzmanlar, teröristlerin hassas (yumuşak) hedefler seçmeye devam edeceklerini, saldırılarını daha az fark gözeterek (daha gelişi güzel) yapacaklarını, terörizmin kurumsallaşacağını ve silahlı bir güç olarak coğrafi bazda yayılacağını ve medyanın terör olaylarını yayınlamadaki artan yetkinliği sebebiyle halkın terörizme her zamankinden daha çok şahit olacağını tahmin etmektedirler (Atkinson vd. 1987; Jenkins 1988). Jenkins'e (1988) göre, terörizmin rutin ve neredeyse göz ardı edilebilir hale gelmesi dolayısıyla sıra dişı güvenlik önlemleri de kalıcı ve hayatın kabul edilen bir parçası haline gelecektir. Çoğu Birleşik Devletlerde yakın zamanda gerçekleşen ve arka arkaya gelen terör saldırıları (1993 Dünya Ticaret Merkezi'nin bombalanması, 1995 Oklahoma City'nin bombalanması, 1996 Suudi Arabistan'daki Birleşik Devletler üssünün bombalanması, 1996 Atlanta'daki Centennial Olimpik Park' 'nda patlayan bomba, 1996 Chicago'nun O'hare Uluslararası Havalimanı pistinde tespit edilen ve patlatılan boru bombası) sıkı güvenlik önlemlerine yol açmıştır, ki bu da Jenkinson'un tahminin ilk kısmını doğrular niteliktedir.

Terörizmin geleceği tartışmasında, 1995'te düzenlenen 10. Yillık Kriminal Adalet Meseleleri Sempozyumu'nda, konuyla ilgili yeni eğilimler tanımlanmıştır:

1. 1970 ve 80'lerdeki Marxist/Leninist terör eylemlerinin çoğunun yerini İslami tutuculuk almıştır. 2. Gerekli silahları, ikmali, finansmanı, koordinasyonu, eğitimi ve terörizmi sürdürmek için gereken güvenli sığınakları sağlayan terörist devletler 1980 lerde Moskova, Havana, Sofya ve Doğu Berlin iken 1990'larda Iran, Irak, Libya, Kuzey Kore, Sudan ve Suriye olmuştur. 3. Teröristler ile grup üyeleri arasindaki bağlantıları çözmek, büyük terör grupları arasında artan iş birliği ve örgütsel doğalarındaki değişim (planlı saldırılardan değişken saldırllara geçiş) yüzünden daha zor bir hale gelmiştir. 4. Teröristlerin kitle imha silahlarl kullanma ihtimalinin artmasıdır. Bu tip bir silahla ilk kitle imha denemesinin (1995 Japonya'da, 12 kişiyi öldüren ve işine giden 5500 kişiyi yaralayan "sarin" gaz saldırısl) kayda geçmesi, terörizmin rahatsız edici gerçekliğini dünyaya göstermiştir (Ranstorp 1996; ABD Dışişleri Bakanlı̆̆̆ 1996). 
Dünya üzerindeki milletler misilleme olarak, terörle mücadele, güvenlik güçleri ve istihbarat toplama faaliyetlerinde güç birliği yapmaya başlamıştır. Terörizmle mücadele konunda stratejiler geliştirmek amacıyla çeşitli konferanslar ve zirveler organize edilmiştir. 1995'te Şili, Brezilya, Paraguay, Uruguay ve Amerika Birleşik Devletleri'nden yetkililer, Arjantin'de bir bölgede terör tehdidine karşı alınacak önlemleri tartışmak amaciyla bakanlar kurulu toplantisına katılmışlardır (ABD Dışişleri Bakanlığı 1996). Halifax Zirvesi tarafından kurulan mandaya karşı olarak, Ottowa'da Aralık ayında bir konferans düzenlenmiş ve Kanada, Fransa, Almanya, İtalya, Japonya ve Birleşik Devletleri (Örneğin G-7) ve Rusya gibi devletlerden yöneticiler katılmıştır. 1996'da 6 adet uluslararası terörle mücadele toplantısı yapılmıştır. Bunlar; Mısır'da Başkan Clinton ve Başkan Mübarak tarafından ev sahipliği edilen "Arabulucular Zirvesi"; Filipinler ve Japonya'nın ev sahipliği ettiği Asya ve Pasifik konferansları, Lima'da gerçekleştirilen ve Peru tarafından ev sahipliği edilen Amerika kıtası özel konferansı ve G-7 ve Rusya bakanlarının katılım gösterdiği Paris'teki toplantılardır.

Birleşik Devletlerde Başkan Clinton, 1996'da 'Anti terörizm ve Uygulanabilir Ölüm Cezası' yasasını imzalayarak yürürlüğe koymuş ve bu yasa ile federal hükümeti, terörizme karşı verdiği savaşta daha güçlü hale getirmiştir. Clinton yönetimi aynı zamanda diğer milletlerle yeni suçlu iade anlaşmalarına dair görüşmeler yapmış ve ülkesindeki teröristlerin ve terörist gruplarının varlığını önlemeye çalışmıştır. Birleşik Devletlerin terörle mücadele politikaları; teröristlerle asla anlaşma yapılmaması ve şantaja teslim olunmaması; teröristlere suçlu olarak muamele edilmesi; teröristlerin kararlı bir şekilde takip edilmesi ve yasaların gücünün uygulanması; ekonomik, diplomatik ve siyasi yaptırımlar uygulayarak ve diğer devletleri de bu şekilde davranmaya teşvik ederek, teröristleri maddi-manevi destekleyen ülkelere olabildiğince baskı uygulanması şeklinde üç genel ilke üzerinde durmaktadır (ABD D1şişleri Bakanlığ 1997).

Siyasi istikrarsızlık, hükümetin, devrilmesi veya askeri bir darbe sonucu belirli gruplar tarafın- dan yönetilmesi veya toplumsal düzenin kontrol ve devam ettirilmesi için gereken temel fonksiyonların, istikrarsız veya kısmen bozulmuş bulunduğu ülkelerin durumunu ifade etmektedir (Cook 1990). 1991 yılında Yugoslavya'nın dağılmasi ve sonrasinda Bosna Hersek'te patlak veren savaş; Burundi, Haiti, Hindistan, Pakistan, Ruanda, Somali ve Güney Afrika'daki rrksal, etnik ve dini çatışmalar; Çin ve Kuzey Kore'deki öğrenci ayaklanmaları ve Ortadoğu'da sürmekte olan Arap-İsrail çatışmaları, hiç kuşkusuz günümüzde fazlasıyla bilinen siyasi anlaşmazlık örnekleri arasındadır. Bu örnekler, dünya üzerinde bir çeşit siyasi çatışma yaşayan ülke sayısının, barış ve istikrar içinde yaşayan ülke sayısını geride bıraktığını göstermektedir.

Terörizm ve siyasi istikrarsızlık birbirinden bağımsız düşünülecek kavramlar değillerdir (Wieviorka 1994; Hall ve O'Sullivan 1996; Lea 1996). Wieviorka (1994), siyasi krizlerin nihayetinde nasıl terörizmle sonuçlanabileceğini göstermek amacıyla Lübnan, İtalya ve Batı Almanya'yı örnek olarak kullanmıştır. Aslında, terörizmin yanı sıra uluslararası, bölgesel ve iç savaşlar, soyk1rımlar, sıkıyönetimler, askeri darbeler ve isyanlar da; Ortadoğu, Balkanlar ve Doğu Afrika'da görüldüğü gibi hem belirli ülkelerin hem de tüm bölgenin güvenliğini tehdit edecek siyasi problemlere yol açabilmektedir. (Wieviorka 1994; Hall ve O'Sullivan 1996). Siyasi istikrarsizlık ve terörizm arasındaki güçlü bağlantı, bazı kaynaklarda bu iki kavram arasındaki ayrımı yapmanın neden zor olduğunu açıklayabilir. Farklı özelliklerine rağmen hem siyasi istikrarsızlık hem de terörizm, turizmi fazlasıyla etkilemektedir. Terör eylemleri çok kısa bir süre içerisinde ve hızlıca gerçekleşmekte ve kitle iletişim araçlarının yoğun yayınları sayesinde halkın dikkatini hemen çekebilmektedir. Medyanın terörizm kadar ilgi göstermediği siyasi anlaşmazlıklar ise uzun süreli etkilere sahip olmakla beraber etkilenen destinasyonlarda seyahatleri büyük ölçüde sekteye uğratabilmekte ve uluslararası turizmi de belli seviyede sabote edebilmektedir. Neyse ki siyasi anlaşmazlıklar veya savaş çerçevesinde turizm meselelerinin incelenmesi son zamanlarda daha çok ilgi çekmektedir (Richter 1983; Teye 1986; Scott 1988; Teye 1988; Hollier 1991; Schwartz 
1991; Gartner ve Shen 1992; Hall 1994). Turizm ve siyaset arasındaki ilişkiyi anlamaya çalışanlara, Tourism and Politics: Policy, Power and Place (Hall 1994) ve Tourism, Crime and International Security Issues (düz. Pizam ve Mansfeld 1996) gibi kaynakları incelemeleri önerilebilir. Ayrıca 1995'te Mid Sweden Üniversitesi tarafından organize edilen "Talk at the Top International Conference on Tourism Security and Risk" adlı konferansta sunulan bildirilerin de hali hazırdaki kaynaklara katkı sağlaması açısından önemli kaynaklar arasında gösterilmektedir. Önerilen ilk kaynak; turizm ve suç; turizm ve politik istikrarsızlık; turizm ve savaş ve suç ve turizm endüstrisi olarak dört kısma ayrılmış bir kitaptır. İkinci kaynak ise turist güvenliği ve riskleri, suç, terörizm ve

Tablo 1. Terörizm veya Siyasi Kargaşanın Turizmi Etkilediği Ülkelere Örnekler

Çin: 4 Temmuz 1989'da, Çinli yetkililer, tüm dünyanın gözü önünde Pekin'in Tiananmen Meydanı́ndaki öğrenci protestolarına acımasızca müdahale etmişlerdir. Askeri tankların ve kaosun haberlerde yayınlanması ile Çin Halk Cumhuriyeti, kendisini resmi olarak uluslararası terörizme açmıştır. Hükümetin dünya görüşü oldukça olumsuz bir hal almıştır. Bu kargaşanın sonucu olarak Pekin'deki doluluk oranı \%30'un altına inmiş, yaklaşık 11.500 kişi seyahat planlarını iptal etmiş ve turizm gelirleri 1989'da 430 milyon dolarlık bir düşüş göstermiştir (Gartner ve Shen $1992 ;$ Hall ve O’Sullivan 1996).

Mısır: Uç fikirlere sahip yerli bir grup olan ve Başkan Hüsnü Mübarek hükümetinin yerine İslamcı bir hükümet getirmeyi hedefleyen Al-Gama'at al-Islamiyya Grubu (İslamcı Grup), 1970'lerin sonunda etkili olmaya başlamıştır (ABD Dışişleri Bakanlığı 1996). Grup 1992'den beri, özellikle Mısır’ın turizm sektörünü hedef almış ve bu sektöre yönelik saldırılar düzenlemiştir. 1992-1995 yılları arasında turistlere yönelik 120'nin üzerinde saldırı gerçekleştirilmiş ve bu saldırılarda 13 turist hayatını kaybetmiştir. Mısır’ın yurt dışından gelen ziyaretçi sayısında \%22, geceleme sayısında \%30 ve turist gelirlerinde \%43'lük düşüş görülmüştür (Aziz 1995; Wahab 1996). Bu kriz, Mısır'ın uluslararası tur operatörlerinin programlarından kaldırılmasına neden olmuştur. Turistlere yönelik son terörist saldırısı ise 1996 yılı Nisan ayında gerçekleştirilmiş ve Kahire'deki 18 Yunan turist bu saldırıda hayatını kaybetmiştir.

Fiji: Fijili olmayan bir hükümetin seçimlerden galip çıkmasının ardından Fiji'de 1987 yılında sadece birkaç ay içerisinde iki askeri darbe yaşanmış$\operatorname{tr}(14$ Mayıs ve 28 Eylül). Bölgede ki Turizm sektörüne yönelik darbeler ise Medyanın sansasyonel yayınları ile başlamış ve bu durumu Avustralya ve Yeni Zelanda'nın yeni seyahat tavsiyeleri takip etmiştir. Illk darbeyi Fiji'nin Nadi Havalimanı'nda Air New Zealand şirketine ait bir Boeing 747 tipi uçağın kaçırılmaya çalışııması takip etmiştir (Hall ve O’Sullivan 1996; Lea 1996; Scott 1996).

İsrail: 1948'deki kuruluşundan bu yana işgal edilmiş bölgelerde yaşayan İsrailliler ve Filistinliler devamlı bir kargaşa içinde yaşamaktadırlar. 1987'deki Filistin ayaklanması (Intifada) bu kargaşayı büyütmüş ve Müslüman Kardeşliğinin Filistin dalından katlımlarının artmasıyla, İsrail'in yerine bir İslamcı Filistin Devleti kurmak amacıyla İslamcı Direniş Hareketi (HAMAS) oluşturulmuştur (ABD Dışişleri Bakanlığı 1996). Gerek İsrailliler gerek Filistinliler tarafindan yapılan saldırılar çok sayıda can kaybına neden olmuştur. 1970-1994 yılları arasında gelen turist sayısında yavaş bir artş̧ görülse de yaşanan olumsuz olaylardan sonra sert düşüşler dikkatlerden kaçmamıştır (Bar-On 1996).

Meksika: Kuzey Amerika Serbest Ticaret Anlaşması (NAFTA) 1 Ocak 1994'te yürürlüğe girdiği zaman Efercito Zapatista de Liberacion Nacional (EZLN), Meksika hükümetine karşı silahlı bir isyan başlatmıştır. Çeşitli kaynaklara göre ayaklanmanın ilk 12 gününde 145 ile 500 arasında insan hayatını kaybetmiştir. Askeri birlikler, Güneydoğu Meksika'nın Chiapas bölgesinde yollara barikatlar kurmuş ve gelen araçları aramışlardır. Mart 1994'te sevilen başkan adayı Luis Donaldo Colosia'nın suikasta kurban gitmesi, Meksika'da daha büyük bir gerginliğe yol açmıştır. Zapatistas grubunun elindeki en büyük kent olan ve hem ayaklanmaların hem de pazarlıkların yapıldığı Chiapas'taki San Cristobal kenti, hem uluslararası hem de yurt içi turizminde büyük kayıplar yaşamaya maruz kalmıştır. Sonuç olarak 1994 yılı Ocak ve Şubat aylarında önceki yılın aynı aylarına göre gerçekleşen turist ziyaretlerinde \%70'lik bir düşüş yaşandığı kaydedilmiştir (Pitts 1996).

Kuzey irlanda: 1996 yılında Geçici Cumhuriyet Ordusu (PIRA), Sinn Fein (Kuzey İrlanda'daki Britanya yetkilerini ortadan kaldırmak ve İrlanda Cumhuriyeti ile birleştirmek amacıyla hareket eden yasal bir politik harekât) gizli bir silahlı gücü olarak kurulmuştur (Ni Aolain 1996; ABD Dışişleri Bakanlığı 1996). Bu grup, Kuzey İrlanda'daki üst düzey İngiliz yetkilileri, İngiliz asker ve polislerini hedef almaktaydı. Gerçekleştirilen bu terör eylemleri ve İngiliz birliklerinin misillemeleri, bölgedeki turistik faaliyetleri ciddi derecede kısıtlamıştır. Risk ve tehlike imajının sonucu olarak 1967 yılında 1.080.000 ile zirve yapan ziyaretçi sayısı, 1976 yılında 321.000'e kadar düşmüştür (Witt ve Moore 1992; Buckley ve Klemm 1993; Wall 1996). 31 Ağustos 1994'te yürürlüğe konulan ateşkes, 9 Şubat 1996'da Londra'da 2 kişinin ölümüne ve 43 kişinin yaralanmasına yol açan patlama ile sonra ermiştir. 18 aylık ateşkes süresince Kuzey İrlanda Turist Kurulu, bir önceki yıla göre turistik talep sayısında \%59'luk, otel doluluk oranlarında \%11'lik, yurt dışından gelen ziyaretçi sayısında \%18'lik ve tatile gelenlerin toplam sayısında \%68'lik bir artı̧̧ gözlemlemiştir (O’Neill ve Fitz 1996).

Peru: The Sendero Luminoso (Işıklı Yol), mevcut Peru kurumlarını köylülerin devrimci rejimiyle değiştirmek ve Peru'yu yabancı etkilerden kurtarmak için 1960'ların sonunda kurulmuş Maocu bir terörist grubudur (ABD Dışişleri Bakanlığı 1996). Bu grubun gerçekleştirdiği saldırılar sonucunda sadece 1989 yılında 350.000 olan uluslararası turist sayısını 1991 yılında 33.000'lere kadar düşmüştür (Wahab 1996). Rakip bir terörist grubu olan ve hapsedilen isyancıların serbest bırakılmasını talep eden Tupac Amaru Devrim Hareketi (MRTA) ise 17 Aralık 1996 'da Japonya Büyükelçiliği'ni basmış ve 500 kişiyi rehin almıştır. İsyancılar ile Peru askeri birlikleri arasındaki gerçekleşen pazarlıklar 126 gün sürmüş ve bu süre zarfinda rehineler, küçük gruplar halinde serbest bırakılmıştır. 24 Nisan 1997'de ise kalan 72 rehine de, askerlerin başarılı kurtarma operasyonu sayesinde kurtarılmıştır. 
Tablo 1. Terörizm veya Siyasi Kargaşanın Turizmi Etkilediği Ülkelere Örnekler (Devam)

Slovenya: Yugoslav ordusu Haziran 1991'de Slovenya'ya saldırmıştır. Ordunun 1991'de Hırvatistan'a ve 1992'de Bosna Hersek'e saldırmasına kadar süren Slovenya savaşı 10 günde sona ermiştir. Fakat bunun sonuncunda, 1991'de Yugoslav uzman tur operatörleri, rezervasyonlarını yaptırmış bir milyondan fazla turisti kaybetmiştir. Hatta 10 günlük savaşın üstünden 2 yıl geçmesine rağmen Sloven turizm rakamları savaş öncesi sayıların altında kalmaktan kurtulamamıştır. 1993'teki geceleme sayılarında 1990 yılına göre \%32 azalma kaydetmiştir (Mihalic 1990 ).

Ispanya: Bask Anavatanı ve Özgürlük (ETA), İspanya'nın Bask bölgesinde bağımsız bir ülke kurmak için 1959'da kurulmuş bir örgüttür (ABD Dışişleri Bakanlığı 1996). Ana hedefleri politikacılar, askeri personel ve hükümet yetkilileri olmakla beraber ETA, 1984-1987 yılları arasında özellikle İspanya turizmini hedef almış, otelleri ve seyahat acentelerini bombalamıştır. ETA'nın yazdığı ve turistlerin hedef alınacağını belirten 200'ün üstünde mektup yabancı elçiliklere, seyahat acentelerine ve İspanya'daki yabancı kanallara gönderilmiştir (Enders ve Sandler 1991). ETA 1996'daki 'yaz faaliyetleri' çerçevesinde Temmuz aynının başında 6 bombalama olayına imza atmış ve Barselona yakınlarındaki Reus Havalimanında 35 kişinin yaralanmasına sebep olmuştur. Bunun yanı sıra İspanya'nın Dorada kıyısı boyunca bulunan otelleri bombalamıştır. Bombalamaların sonuç olarak ise turizm faaliyetlerinde olumsuz hareketlenmeler kaydedilmiştir (Bar-On 1996). Tibet: 1987 'de başlayan milliyetçi kargaşa, Mart 1989'da Lhasa'da sıkıyönetim ilan edilmesi ile noktalanmıştır. 1990'da Kathmandu'da, demok-
rasi öncesini anlatan çizimlerin fotoğraflarını çeken üç yabancı vurulmuş ve bunlardan biri hayatını kaybetmiştir. Bu durumun akabinde ise Tibet
turizminde ciddi hasarlar yaşanmıştır. 1988 yılında Tibet'e gelen ziyaretçi sayısı 22.000 iken, 1989 yılının ilk altı ayında bu sayı 1.092 olarak kayda
geçmiştir (1988'in ilk altı aylık sürecinde bu sayı 5.000'dir). Hükümetin ziyaretçi beklentilerinin sadece \%3,1'i gerçekleşirken turizm işletmeleri
tarafindan 4.52 milyon yuanlık kayıp olduğu bildirilmiştir (Schwartz 1991).

Gambiya: 1965 yılında Britanya'dan bağımsızlaşmasının ardından siyasi istikrarın sürdüğü bu küçük ülke gelişmekte olan bir Batı Afrika ülkesidir. Ülkede 1994 yazında, kansız bir askeri darbe gerçekleştirilmiştir. Olay onucunda, İngiliz Seyahat Öneri Birimi (FCO), Gambiya karşıt birtakım sert seyahat uyarılarında bulunmuş ve bunun sonucunda önce İngiliz sonra da İskandinav tur operatörleri, ülkenin turizm sektörünü bitirmek pahasına bu ülkedeki faaliyetlerini durdurmuşlardır. Ülkeye gelen turist sayısı 5.000'den 300'e düşmüş, doğrudan veya dolaylı olarak turizme bağlı 2.000 iş kolu yok olmuş, 8 otel kapanmış ve ülkenin ekonomik ve sosyal şartları hızlı bir şekilde kötüleşmeye başlamıştır (Sharpley ve Sharpley 1995).

Türkiye: Bağımsız Marksist bir ülke kurma çabasındaki asi bir Marksist-Leninist grup olan Kürdistan İşçi Partisi (PKK) 1974 yılında Türkiye'nin Güneydoğu bölgesinde kurulmuştur (ABD Dışişleri Bakanlığı 1996). Günümüze kadar PKK, öncelikli olarak Türk hükümet güçlerini ve sivilleri hedef almıştır. 1993 yılından bu yana PKK örgütü, Türk hedeflerine karşı Batı Avrupa'da daha aktif olmaya başlamış ve 1991'den beri özellikle Türk turizm sektörünü hedef almıştır. ETA'nın mektup kampanyasından ilham alan PKK yabancı şirketlere, Türkiye'ye turist gönderilmemesi için uyarıcı mektuplar göndermiş, turizm bölgelerini ve otelleri bombalamış ve yabancı turistleri kaçırma faaliyetlerinde bulunmuştur. 1992-1993 yıllarına nazaran yabancı turist ziyaretlerinde \%8'lik bir düşüş gözlemlenmiştir (Bar-On 1996). PKK'nın gönüllü olarak ilan ettiği ateşkesin ardından ise 1996'da yurt dışından gelen turist sayısının rekor seviyelere (9.5 milyon) ulaştı̆ı gözlemlenmiştir.

Zambiya ve Zimbabve: Önceden Güney Rhodesia olarak bilinen Zimbabve'nin 1965'teki Tek Taraflı Özgürlük Illanı (UDı)’nın ardından 15 yıl sürecek ve 1990 yılında sona erecek olan özgürlük savaşı başlamıştır. Bunun sonucu olarak, komşu Zambiya'yı da ilgilendiren bölgedeki turizm sektörü sekteye uğramıştır. Teye'ye (1986) göre Kenya'ya gelen turist sayısı 1964-66 yıllarında 250.400 iken $1970-78$ yıllarında 3.524.000'e çıkmış fakat Zambiya'da aynı dönemlerde çok az bir artış olduğu (429.700-466.800) görülmüştür. 1967-69 yılları arasında Zambiya'da, savaş yüzünden herhangi bir turist ziyareti kaydedilmediği ortaya çıkarılmıştır.

konuk ağırlama kriz yönetimi meselesi üzerine yoğunlaşan ve alanda gerçekleştirilen tek konferansta sunulan yayınların bir derlemesidir.

İlginç bir şekilde uluslararası terörizm ve turizm kavramları belli başlı ortak özelliklere sahiptir. İkisi de ülke sınırlarını aşmakta, farklı ülkelerin vatandaşlarını kapsamakta ve seyahat ve iletişim teknolojilerinden faydalanmaktadır (Schlagheck 1988). Hatta bu durum iki kavram arasındaki ilişkiyi yıllar boyunca sayısız haber bülteninin konusu haline getirmiştir. Şu bir gerçektir ki, tesadüfi terör eylemleri turistleri korkutmakta ve halk bu eylemleri unutana kadar bu durum ülkedeki turizmin akışını sınırlamakta veya değiştirmektedir. Diğer bir taraftan, bazı ülkeler de sürekli olarak arz eden terörizm, ülkenin olumlu imajını lekelemenin yanı sıra ülkedeki turizm sektörünü tehlikeye atmaktadır. Sürekli hale gelen terör saldırıları turistlerin algılarını değiştirdiği zaman veya teröristlerin özellikle bu sektörü hedef aldığı zaman, turizmin acı çekmesi kaçınılmaz olacaktır. Terörizm veya siyasi kargaşanın turizmle kesiştiği ve turistik faaliyetlerin engellenmesine ya da turist tipinin değişmesine yol açtı̆̆ örnek ülkeler Tablo 1'de belirtilmiştir. Bu örnekler Wahab'in (1995) terörizmin her toplumun kendine has karakteristik özelliklerini sömürdüğü iddiasını doğrulamaktadır. Ülkeler farklı koşullara sahip olmasına rağmen, turizm sektörleri şiddeti değişmek üzere benzer zorluklara mazur kalır. 


\section{Terörizm - Turizm İlişkisi}

Terörizm ile turizm arasındaki ilişkiyi çözmek, teröristlerin hedeflerinin ne olduğunu anlamak konusunda fayda sağlayacağını düşünmek mantıklıdır. Teröristleri neyin güdülediği konusunda hemfikir olmak zor olsa da terörizm - turizm ilişkisinin doğasını açıklamayı hedefleyen birtakım çalışmalar bulunmaktadır. Alanyazın açıkça belirtmektedir ki turistler veya turizm sektörü kasıtlı bir şekilde hedef alınmaktadır ve teröristlerin amaçlarına (örn: propaganda, ekonomiyi bozma, turizme ideolojik karşı çıkış) ulaşmalarında etkili bir yoldur. Konu hakkında yazılan ilk makalelerden birinde Richter (1983), uluslararası turizmin huzurlu bir biçimde sürmesi ile diplomatik ilişkiler arasındaki paralellikleri belirterek terörizm - turizm ilişkisinin sembolik doğasını göstermektedir. Richter'e göre turistlerin hedef alınmasının sebebi turistlerin, ülkelerinin temsilcileri, kolay hedefler ve 'muhalif hükümetin dolaylı temsilcileri' olarak görülmeleridir (Richter 1983; Richter ve Waugh 1986). Bu durum, 1985 yılında Filistinli teröristlerin Achille Lauro yatını kaçırmalarıyla acı bir şekilde örneklendirilebilir. Çünkü yattaki tek Yahudi Amerikan'ın öldürülmesi rastlantı ile açıklanamaz. Geçen zamanla birlikte de dünyada, uluslararası turizmin siyasi öneminin teröristlerce anlaşıldığına dair trajik olaylara şahit olunmuştur. Richter'e (1983) göre başka ülkelerin vatandaşlarını kapsayan terör eylemleri, siyasi özgürlüklere karşı koyulan sert kısıtlamalara bir cevap niteliğinde görülebilmektedir çünkü saldırgan hükümetin kontrolündeki basın, kendi vatandaşlarının başına gelen terör olaylarını örtbas etme eğilimindedir. Sebebi basit ve açık olan durum sayısız olaylarla kanıtlanmıştır: farklı ülke vatandaşlarının dâhil olduğu olaylar haber bültenlerine kesinlikle yansımaktadır. Bu sayede teröristler, kendi hükümetlerinin kısıtlama ve sansürlerini engelleyerek basından gerekli ilgiyi göreceklerini bilmektedirler. Turistler kaçırıldıklarında veya öldürüldüklerinde, olay medya tarafından hemen yayınlanır ki bu da teröristler ile devlet arasındaki siyasi çatışmanın dünya çapında bilinmesine yol açmaktadır. Teröristler istedikleri etkiyi bırakırlar ve medya da bu etkinin yayılmasına ve artmasına yardımcı olur (Richter 1983).
Teröristlerin hedefleri, genel olarak devrimci (rejimin devrilmesi gibi hükümet karşıtı hedefler) ve devrimci olmayan (politika ve eleman değişimleri) hedefler olarak sınıflandırılmıştır. Daha detaylı olarak terörist hedefleri; ideolojik, stratejik ve taktiksel hedefler olarak sinıflandırılabilir (Richter ve Waugh 1986). İdeolojik hedefler uzun vadeli hedeflerdir ve ulusal bir mücadele gerektirebilir. Kısa vadeli olan ve yasal endişelerden kaynaklanan taktiksel hedefler ise genellikle soygunları içermekle birlikte zengin turizm bölgelerini, saldırılara karşı savunmasız olan turistlerin bizzat kendilerini ve sosyoekonomik ve siyasi elitlerin yaşadığı bölgeleri hedef almaktadır. Taktiksel saldırılar, büyük ölçüde alışılmış günlük suçlara benzerlik göstermektedir. Richter ve Waugh'a (1986) göre teröristler, stratejik amaçlarını gerçekleştirmek için turistleri hedef alarak turizm sektörünü baltalarlar ve böylece daha bilinir hale gelirler. Ayrıca, teröristler, ihtiyaç duydukları kaynakları karşılamak için farklı turist gruplarına ve kuruluşlara yönelmekten çekinmezler. Yabancı dil konuşan ve yabancı görünen geniş gruplar, teröristlere hem saklanma ve güvenlik imkânı hem de hedef seçme imkânı sağlamaktadır. Teröristler, hiç şüphe uyandırmadan turistlerin arasında gezebilir ve döviz kullanarak alışveriş yapabilirler (Richter ve Waugh 1986). Bu bağlamda düşünüldüğü zaman, teröristler; ideolojik amaçlarını gerçekleştirmek, hükümeti destekleyen vatandaşları cezalandırmak ve hükümeti zayıf göstererek siyasi meşruiyet iddialarını güçlendirmek için turistleri hedef alma eğiliminde bulunmaktan çekinmezler (Hall ve O'Sullivan 1996).

Konu üzerine çalışanlar, terörizmin hedeflerini farklı biçimlerde tanımlasalar da turistleri hedef almanın teröristler için çok kazançlı olduğu konusunda hemfikirdirler. Turizm, kapitalizmi simgeleyen bir olgu olduğunda ve devlet tarafından da desteklendiğinde, sektöre yapılan saldırılar devlete de yapılmış sayılmaktadır. Turizm sektörü önemli bir ekonomik faaliyet kaynağı olduğu için teröristlerin turistlere karşı gerçekleştirdiği saldırılar, ülkeye giren döviz miktarının düşmesine sebep olarak hükümete ilave ekonomik yük bindirmekte ve teröristlere devlet yetkililerinden daha fazla siyasi güç sağlamaktadır 
(Hall ve O'Sullivan 1996; Richter ve Waugh 1986). Edgell'e (1990) göre turistlerin kendi ülkelerinde kalma veya nispeten daha güvenli destinasyonlara gitme kararları, terörizmden mustarip ülkelerin turizm sektöründe büyük kayıplar yaşaması anlamına gelmektedir. 1992'de başlayan terör saldırıları sonucunda Mısır'daki döviz gelirindeki \%43'lük düşüş, teröristlerin bir ülkenin ekonomisine ne denli zarar verebileceğinin açık bir kanıtıdir (Wahab 1996).

Bazı çalışmalar, terörizm-turizm ilişkisine dair geçerli sosyoekonomik ve kültürel açılamalar da sunmaktadır (Richter 1983; Aziz 1995; Wahab 1995; Lea 1996; Wahab 1996). Richter'e (1983) göre turizm, "turizm gelişiminin destekçileri ve karşıtları arasında bölücü çatışmalara sebep olma" potansiyeline sahiptir. Benzer şekilde Richter'e göre yabancı iş adamları ve turistik tesisler, sosyoekonomik ve siyasi elitlerin turizm sektörü üzerindeki kontrolüne karşı çıkan teröristler için mantıklı hedefler olabilme potansiyeline sahiptirler. Turizmin "yerli sanayi ve kültürün bozulmasından sorumlu olduğu" düşünüldüğünde, bölgede yaşanan turizm gelişiminin yerli halka fayda sağlamadığı algısı şiddetli olaylara yol açma ihtimaline sahiptir (Richter ve Waugh 1986). Lea'nın (1996) “Turizmin gelişmesinde rol alanların, toplum desteğini de arkalarına alacak bir şekilde projelerini tasarlama, yerleştirme ve yönetmedeki olası başarısızlıkları, nihayetinde halkın karşı çıkmasına ve şiddete yol açacaktır." ifadesi de bu görüşü destekler niteliktedir. Yerel halkın turizm sektörüyle ters düşmesi sonucu muhalefetin ve şiddet olaylarının patlak vermesi ihtimal dâhilindedir (Lea 1996).

Mısır'daki terörizm tartışmasında Aziz (1995), İslam'ın sadece yabancı turistlere karşı olduğuna yönelik yanlış geliştirilen kanıya sosyoekonomik bir açıklama ile itiraz etmektedir. Aziz'e göre Misır'daki turistler ve yerliler, hem dil hem de ekonomik ve sosyal farklılıklar yüzünden birbirinden ayrılmaktadırlar. Fakirlikten mustarip olan yerli halk, lüks içindeki yabancı turistlerle yaşamaya zorlandıkları zaman sürtüşme kaçınılmaz bir hal almaktadır. Aziz'in bu konuya ilişkin açıklamaları, Richter'in (1983) seyahat şekillerinin ideolojik değerleri, sınıf farkını ve turistlerin ve ülkelerinin siyasi kültürlerini yansıtabileceği açıklamasını destekler niteliktedir. Sonuç olarak turistlerin hedef alınma sebebi, kayda değer bir tüketimi (harcamayı) yansitan turizm göstergeleri (örn: para ve kredi kartının gösterilmesi, gösterişli fotoğraf makineleri, pahalı kıyafetler, takılar ve valizler) olarak gösterilebilir. Turizmle oluşan kızgınlık, bu kızgınlığın tehlikeli bir şekilde ifade edilmesine yol açabilmektedir. Bunların yanı sıra, yerel halk ve turistler arasındaki sürtüşmeler, çatışan kültür ve değerler nedeniyle de meydana gelebilir. Hatta, turistlerin İslam kültürüyle örtüşmeyen belirli davranışları da (örn: domuz eti ve alkol tüketimi, kumar, batılı tarzda kıyafetler, İslam gelenekleriyle uyuşmayan davranışlar) Mısırlıların kızgınlıklarının altında yatan muhtemel nedenlerden biri olarak değerlendirilebilir (Aziz 1995). Wahab (1995) bazen terörizmin özellikle turizmi hedef aldığını belirtmektedir çünkü turizmin, "yeni bir sömürgecilik hareketinin temsilcisi ve turistlerin de köklü toplumsal kurallar, gelenekler, değerler sistemi ve dini inançlara karşı bir tehdit oluşturan 'yabanc1' ziyaretçiler olarak" algılanması onu bu fikre inandırmıştır. Wahab'ın (1995), Mısır'da turistlere karşı yapılan terör saldırılarının, çağdaşlığın yozlaştırılmasına direnmek amacıyla gerçekleştirilen eylemler olarak saldırganların klasik İslami toplumsal kuralları yeniden canlandırma isteklerinin yansıtıldığına yönelik açılaması Richter ve Waugh'un (1986) “Yerel halkla turistler arasındaki basit temaslar yüzünden kültürün kirlenmesinin" sorumlusu olarak turizm görüldüğü zaman ' uyuşmazlıkların ortaya çıkacağı' söylemini desteklemektedir. Daha muhafazakâr yerliler veya Müslüman aktivistler; milli kültürlerine, geleneklerine ve dini inanışlarına tehdit olarak gördükleri şeyleri engellemek için kalıcı önlemler almaları gerektiğini düşünebilmektedirler (Wahab 1995). Maalesef ki uç durumlarda, kutsal inançlar1 koruma isteği terörizme dönüşmektedir.

Basitçe söylemek gerekirse alanyazın, turizmi teröristler tarafından başlatılan bir iletişim biçimi veya bu iletişimde kullanılan bir mesaj olarak göstermektedir. Yani, turizm; siyasi, dini, sosyoekonomik veya kültürel anlaşmazlıkları tetikleyerek terör olaylarını da beraberinde getirebilir. Benzer şekilde turizm, ideolojik/siyasi çatışma- 
ları geniş kitlelere ulaştırmak için etkili bir araç olarak da kullanılabilir. Her iki durumda da turistlerin hedef olarak seçilmesi tesadüfi bir durum değildir. Teröristler için yabancı turistlerin sembolize ettikleri değer, sahip oldukları yüksek profiller ve haber değerleri, istismar edilmeyecek kadar değerlidir. Diğer araştırmacılardan farklı bir bakış açısına sahip olan Ryan (1993) terörizmi, turizmi de kapsayan suçlar kategorisindeki ileri seviye bir suç olarak görmektedir. İlk bakışta terörizm ve suç kavramları bireylere yönelik tesadüfi şiddet olaylarını içermesi ve turizmi tehdit etmesi açısından birbirlerine benzerlik gösterdiği görülmektedir. Ancak bu kavramları birbirinden ayırmak oldukça önem teşkil etmektedir çünkü bu kavramların ortaya çıkmasına neden olan sebeplerin açlk bir biçimde tanımlanmaması çözüm üretmeyi zor bir hale getirecektir. Terörizm, siyasi ve dini nedenlerden dolayı, gündelik suçlardan açık bir şekilde ayrılmaktadır. Fakat kuşkusuz ki suç, bölgelerin kırılganlığı arttırıp güvenli imajını yok ederek turizmi baltalayabilir. Akabinde ise uzun vadeli ve geri döndürülmesi oldukça zor olan pahalı sonuçlar ortaya çıkaracaktır. Miami'deki turistlerin öldürülmesi bölgenin karşılaştı̆̆ 1 zorluklara bir örnek teşkil etmektedir. Alanyazında birçok çalışma, suç ile turizm arasındaki ilişkiyi araştırmıştır (Pizam 1982; Chesney-Lind ve Lind 1986; Demos 1992; Kemmer 1995; Hollinger 1995; Bach 1996; Bloom 1996; Cohen 1996; Lankford 1996; LeBruto 1996; Prideaux 1996; Ryan ve Kinder 1996; Schiebler, Crotts ve Hollinger 1996; Tarlow ve Muehsam 1996).

Yapılan istatistiki çalışmalar, algılanan risk oranının artmasının turizm talebini ciddi derecede değiştirdiğini açıkça göstermektedir. Örneğin 1985 'te altı milyonun üzerinde Amerika vatandaşının Avrupa'yı ziyaret etmesine ve 1986'da yedi milyon kişinin daha gideceğinin öngörülmesine rağmen bu sayının \%54'ü, Avrupa'da terör faaliyetlerin zirve yapması sebebiyle rezervasyonlarını iptal etmiştir (D'Amore ve Anuza 1986). Aynı yıl Newsweek'in yaptığ ${ }_{1}$ Gallup anketine göre Amerikalıların \%79'u o yaz okyanus aşırı ülkelere gitmekten kaçındıklarını belirtmişlerdir (D'Amore ve Anuza 1986). 1986'daki olaylar (Çernobil nükleer felaketi ve Birleşik Devletler ordusunun Libya baskını) Avrupa ziyaretlerini de ciddi ölçüde azaltmıştır. Bazı Avrupa ülkelerine gerçekleşmesi öngörülen seyahatler, tahminlerin gerisinde kalmıştır. Rezervasyonlar, Yunanistan'da \%30, Birleşik Devletlerde \%68 ve eski Batı Almanya'da \%77 azalmaya maruz kalmiştır (Braddy ve Widdows 1988). Akdeniz ülkelerindeki rezervasyonlarda \%50'lik bir düşüş kaydedilirken sadece Misır'da, beklenen Amerikalı ziyaretçilerin sayısında \%65'lik azalma görülmüştür. Dünya Turizm Örgütü, 1985'te turizm sektöründeki 105 milyar dolarlık kaybı terörizme bağlamıştır. Öte yandan terörizm riski ortadan kaldırıldığı zaman turizm hareketlerinde artış yaşandığı da ayrıca görülmüştür. O'Neill ve Fitz (1996), Geçici İrlanda Cumhuriyet Ordusu'nun başlattığı ve Birleşmiş Kral Yanlısı Askeri Komutanın da katıldığg 18 aylık (Ağustos 1994'ten Şubat 1996'ya kadar) ateşkese atıfta bulunarak "Barışın en açık sonuçlarından biri de, ateşkesin ilk yılında Kuzey İrlanda'daki turizm faaliyetlerindeki hızlı yükselişi" olduğunu belirtmeleri bu durumu destekler niteliktedir.

Terörizmin, turizmi olumsuz yönde etkilediği inancı, bu iki olgu arasındaki ilişkiyi ölçen araştırmacılar tarafından, karmaşık metotlar ve bilgisayar modelleri kullanarak turizm faaliyetlerindeki değişiklikleri ortaya çıkarmak amacıyla testler yapılmış ve tutarlı bulgulara ulaşılmıştır. Örneğin; risk olasılığı, turist davranışlarını fazlasıyla etkilemektedir. Bu, hiç kuşkusuz turistlerin karar verme aşamasında ortaya çıkan bir etkidir (Cook 1990; Sönmez ve Graefe 1998). Yapılan çalışmaların ulaştığı diğer bulgulara göre turistler, koruyucu bir önlem olarak; davranışlarını değiştirmekte (Hartz 1989); riskli bölgeler yerine daha güvenli bölgeleri tercih etmekte (Gu ve Martin 1992; Mansfeld 1996); terörizm riskini doğrudan etkilenmeyen komşu ülkelerle ilişkilendirmekte (Enders, Sander ve Parise 1992); terörizme karş1 geç tepkiler vermekte (Enders ve Sandler 1991; Enders vd. 1992) ve riske karş1 verdikleri tepkilerde kültürel farklar göstermekte oldukları sonucuna ulaşılmıştır (Hurley 1988; Tremblay 1989; Wall 1996). Terörizmin turistlerin kararları üzerindeki etkilerine dair geniş çaplı bir inceleme alanyazında henüz mevcut değildir. Zaten karışık olan karar verme sürecine bir de risk faktörünün katılması, muhtemelen bu süreci daha 
da karmaşık hale getirecektir. Bunun yanı sıra, turizm çeşidi (örn: iş veya eğlence) de karar verme sürecini etkileyebilir. Örneğin iş amaçlı seyahat eden turistler, seyahat yerlerine ve programlarına daha bağlı kalmak durumdadırlar. Cook (1990) ve Sönmez ve Graefe (1998), iki farklı evreni kullanarak terörizm ve siyasi istikrarsızlık riski taşıyan seyahat kararlarını incelemişlerdir. Cook'a göre iş amaçlı seyahat edenlerin uluslararası bölgelere olan eğilimleri, onların medyada yayınlanan terör haberleri nedeniyle planlarını değiştirmeleri konusundaki isteksizlikleri ve daha önceki uluslararası seyahatleri tarafından belirlenir. Cook deneklerine, terör riskine karşı verecekleri tepkileri anlamak için hayali durumlar ve ülkeler vermiştir. Deneklerin hayali terör tehditlerine karşı verdikleri farazi tepkiler, gerçek tehlikelere verecekleri asıl tepkilerini yansitmayacağı için Cook'un metodunun gerçekçi cevaplar alma konusunda ne kadar etkili olduğu sorgulanabilir. Benzer bir şekilde Sönmez ve Graefe de bireylerin tatil kararlarını incelemiş fakat geçmişteki yurt dışı seyahat tecrübelerinin şu anki ve ilerleyen süreçteki davranışlara yalnızca dolaylı olarak etki ettiği sonucuna ulaşmışlardır. Sonuçlar ayrıca göstermiştir ki yurt dışında bulunan destinasyonlara karşı sahip olunan pozitif tutumlar ve o destinasyonların sahip olduğu risk seviyesinin düşük olması, bireylerin yabancı seçeneklere yönelmesine ve destinasyon seçerken güvenlik faktörlerine duyduğu ihtiyacın azalmasına neden olmaktadır. Ancak şu göz önünde bulundurulmalıdır ki, bu çalışmanın yapıldığı süre zarfında herhangi bir terör olayı meydana gelmemiştir. Bu nedenle araştırmanın sakin bir ortamda geçmiş olması sonuçları etkilemiş olabileceği göz önünde bulundurulmalıdır. Risk içeren kararları daha somut bir biçimde anlamak amacıyla gerçek durum faktörlerine ihtiyaç vardır (halihazırda bir tehdit, medyanın terörizmle alakalı yayın yapması gibi).

Yukarıda belirtilen kısıtlamalar değerlendirildiğinde iş için seyahat edenlerin teröristlerce hedef alınma riskinin daha yüksek olabileceği söylenebilmektedir. Amerikan çok uluslu şirketlerinin, uluslararası terörizme rağmen devamlı yurt dişına seyahat etmek durumunda olan üst düzey yöneticilerinin incelendiği bir çalışmada
Hartz (1989), bu yöneticilerin, riskleri en aza indirmek adına seyahat sürecinde davranışlarında değişiklikler yaptıklarını gözlemlemiştir. Bilişsel ve duygusal başa çıkma şekilleri, inkâr, gerginlik ve güvenlik gerekçesiyle yapıldığı söylenen davranış değişiklikleri, birçok deneğin kişisel olarak tehlike hissettiklerini ortaya çıkaran geniş kapsamlı röportajlarla incelenmiştir. Örneğin denekler röportajlarda "ucuz kurtulduklarını" (kaçırılan bir uçağa son anda binemediklerini, bombalanmadan hemen önce bir otel lobisinden ayrıldıklarını), "gerçek bir terör saldırısında kurban olduklarını" (örn: kaçırılma, bombalama) veya "kıl payı kurtulduklarını" söylemişlerdir. Tahmin edilebileceği gibi deneklerin çoğu (\%83'ü), kendilerini daha güvende hissetmek için davranışlarını değiştirdiklerini söylemişlerdir. Bu değişikliğin yanı sıra yurt dışı iş seyahati yapanların çoğu, özgürlüklerinin kısıtlandığını, rahatsızlıklarının arttığını ve gerginlik seviyelerinin yükseldiğini de ayrıca belirtmişlerdir. Hartz, güvenli davranışları; dikkat çekmeme, dikkat çekmeyen kıyafetler giyme, şüphe çeken tüketim alışkanlıklarından vazgeçme ve kendini büyük bir şirketin adını kullanarak tanıtmama olarak tanımlamaktadır. İş seyahatine çıkanlar için bu yöntemleri kullanmak ve ülke insanları arasına karışmak mümkün olsa ve turistler bir şekilde davranışlarını değiştirebilseler de, çeşitli özellikleri (örn: kıyafet, davranış, ziyaret edilen yerler) ile yerli halktan rahatlıkla ayırt edilebilirler ve fark edilmeme konusunda ciddi zorluk yaşarlar.

Turistlerin ürünleri fiyat-performans açısından tartıp karar veren mantıklı tüketiciler olduğu vasayımına göre bir tatil destinasyonunda artan terör olaylarıyla ilişkilendirilen riskler, o destinasyonun algılanan maliyetinin turist için artmasına sebep olmaktadır. Bu yüzden bir tatil destinasyonunda ki terör olayları, turistlerin o bölgeyi daha riskli görmelerine (o bölgeyi görme maliyetinin artmasına) ve turistlerin daha güvenli gördükleri tatil destinasyonlarını tercih etmelerine neden olmaktadır (Enders ve Sandler 1991; Enders vd. 1992; Gu ve Martin 1992). Bu görüş, Gu ve Martin (1992)'in çalışmalarının da desteklediği bir görüştür. Söz konusu çalışma tatil yeri değişikliğini, gitmeyi düşündükleri bölgedeki riski gören uluslararası turistler için mantıklı bir çözüm ola- 
rak görmektedir. Gu ve Martin, 1971-1984 yılları arasında Orlando Uluslararası Havalimanı'ndaki (OIA)yolcu trafiğinin artışını açıklamak adına, ikincil veriler kullanarak gelen yolcuları incelemişlerdir. Ortadoğu ve Avrupa'daki teröristlerin uçak kaçırma olaylarındaki artış ile Orlando Uluslararası Havalimanı'na gelen yolcu sayısındaki artış arasındaki bağlantıdan yola çıkan $\mathrm{Gu}$ ve Martin, Orlando ile Avrupa ve Ortadoğu'daki tatil yerleri arasındaki ikame etkisini açıklamışlardır. 1991 İran Körfez Savaşı sırasında da benzer bir durum ortaya çıkmıştır. Savaş sırasında turistler, Avrupa seyahatleri için Karayip ve Kuzey Amerika gemilerini tercih etmişlerdir. Ortadoğu'daki siyasi istikrarsızlık hakkındaki yeni bir çalışmada da benzer bölgesel değişiklikler incelenmiştir. Mansfeld (1996), istikrarsız durumdaki Ortadoğu'nun "iç çember" ülkelerindeki (örn: Mısır, İsrail, Ürdün, Lübnan ve Suriye) turizmin, buradaki Arap-İsrail çatışmaları sebebiyle, nispeten daha istikrarlı durumdaki "dış çember" ülkelerine (örn: Kıbrıs, Yunanistan ve Türkiye) doğru yöneldiğini göstermiştir. Mansfeld'e $(1995,1996)$ göre herhangi bir çatışmada aktif olarak yer almayan bir ülke, potansiyel turistler tarafından bir tehdit olarak görülemez. Mansfeld bu görüşünü, bölgedeki çatışmalar sebebiyle iç çemberdeki ülkelerin kaybettiği ziyaretçileri dış çemberdeki ülkelerin kazandığ teklemektedir. Mansfeld bu durumu "taşma etkisi" (çatışma yaşayan ülkelerin komşularının turizmden kazanç elde etmesi) olarak adlandırmıştır. Mansfeld bir ülkenin ziyaretçilerinin sayısı ile o ülkenin güvenlik durumuyla ilgilenme miktarı arasında doğru orantı olduğunu ayrıca belirtmiştir. Wahab'in (1996) “Bir olaylar zinciri turistleri belirli tatil bölgelerini ziyaret etmekten alıkoyduğu zaman diğer tatil yerleri, uzak veya yakın olmaları fark etmeksizin, bu durumdan faydalanacaklardır" ifadesi de Mansfeld'in $(1995,1996)$ bulgularını destekler niteliktedir.

Bu tip değişiklikleri basitçe tatil yeri değişikliği olarak nitelemek yerine "taşma etkisi" olarak nitelemek zor olsa da, unutulmamalıdır ki bölgedeki turistler, kargaşa halindeki tatil yerlerinden ziyade yakınlarındaki komşu tatil yerlerini rahatlıkla tercih edebilirler. Bölgedeki turistlerin aksine bölge dışından gelen turistler ise, bu ça- tışmaları tüm bölgeye genelleyebilirler. Bu görüş, Körfez Savaşı sırasında Irak'ın komşularında görülen turist sayısındaki düşü ile açılanabilir. Ayrıca, yoğun pazarlama çalışmaları ve döviz kurundaki değişiklikler gibi anlık faktörlerin de seyahat tercihlerinde değişikliklere yol açabileceği unutulmamalıdır. "İkame etkisi", bazı tatil yerlerinin neden diğerlerine nazaran daha fazla tercih edildiklerini, "Genelleme etkisi" ise neden bazı turistlerin bir ülkede terörizm tehdidi algıladıkları zaman tüm bölgeyi riskli görme eğiliminde olduklarını açıklamaktadır (Enders vd. 1992). Sonuç ise komşuları terör olaylarına dâhil olmuş olan bir ülkede, ülke tamamen güvenli olsa bile, turizmde meydana gelen rakamsal düşüşlerdir. Komşuları siyasi kargaşa yaşayan birkaç ülkedeki terörizmin sonucu olarak Avrupa genelindeki seyahat düşüşü, bu konuya güzel bir örnek teşkil etmektedir. Örneğin Irak'taki 1991 Körfez Savaş1 sırasında Akdeniz Bölgesi, turizmde ciddi bir düşüşe sahne olmuştur.

Yazılı ve görsel basının yaygınlığı, insanları terörizm sıklığı ve şiddetinin yansıtıldığı kayıtların hemen o alanlardaki turizmi baltalayacağına inanmaya yönlendirmektedir. Fakat bu konuyla alakalı araştırmalar aksi durumu göstermiş ve turistlerin terörizme verdikleri tepkinin hemen değil daha geç geldiğini işaret etmiştir. İspanya örneğinde Enders ve Sandler (1991), tipik bir terör olayından sonra yurt dışından gelen ziyaretçi sayısının 140.000 civarında düştügünü, fakat bu düşüşün olaydan üç ay sonra başladığını tespit etmişlerdir. Bu bulgu, 12 Avrupa ülkesinde (özellikle Yunanistan, İtalya ve Avusturya) terörizmin turizm üzerindeki etkilerinin incelendiği ikinci bir çalışma tarafından da desteklenmiştir. Enders, Sandler ve Parise (1992), turizmin terör olaylarına yaklaşık 6-9 ay sonra reaksiyon gösterdiğini ortaya çıkarmışlardır. Bu çalışmalarda ikincil veriler kullanıldığı için reaksiyonun neden geciktiğini bulmak zor olmuştur ki zaten bu da spekülasyonlara yol açmaktadır. Şu da bir gerçektir ki uluslararası turizm pahalı bir sektör olduğu için turistler, bir terör olayının hemen ardından planlarını değiştiremeyebilirler veya değiştirmek istemeyebilirler. Hatta turistler, olayın yaşandığ 1 yerde kısa süre içinde yeni olayların yaşanma ihtimalinin düşük olduğunu bile dü- 
şünebilirler. Terör olaylarından sonra devamlı gösterilen haberlerin seyahat akışları üzerinde etkisinin olması ihtimali de, terörizme verilen gecikmeli tepkinin başka bir açıklaması olarak gösterilebilir.

Turistlerin terörizme verdiği tepki tartışmas1nın son noktası da, risklere karşı verilen tepkilerin kültürel farklılıklara göre değişkenlik göstermesidir. Değişik kültürlerin risk algılarının incelendiği çalışmalar, hem risklerin sıralanmasında hem de algılanan risklerin kaynağ 1 ve risklere verilen tepkilerin büyüklükleri açısından farklılıklar olduğunu göstermiştir (Tiegen vd. 1988; Mechitov ve Rebrik 1990; Goszczynska vd. 1991). Benzer bir şekilde, uluslararası turistlerin memleketlerinin terör tehditlerine verdikleri tepkileri belirlemede rol oynadığ 1988; Tremblay 1989). 1985 'te ve 1986 'da yurt d1şından Roma'ya gelen ziyaretçilerin karşılaştırıldığ 1 bir çalışmada Hurley (1988), Amerikalıların ziyaretlerinde \%59'luk bir düşüş olduğunu tespit etmiştir. Çalışmada, Amerikalıların Avrupa ülkelerini ziyaret konusunda "kararsiz" olduğu sonucuna varılmış ve Avrupalı otel işletmecilerinin pazarlama stratejilerini Avrupa ve Asyalı turistlere göre belirlemeleri gerektiğini belirtilmiştir. Amerikalıların kararsız olarak tanımlanması, geçmişteki terör eylemlerinin büyük bir bölümünün Birleşik Devletler vatandaşlarını hedef ald1ğ 1 düşünüldüğünde adil bir tanımlama değildir. Terörün 18 Avrupa ülkesinin turizm gelirleri üzerindeki etkilerini inceleyen başka bir çalışmada ise, gelirlerin turistlerin geldiği ülkelere göre değişiklik gösterdiğini sonucu ortaya çıkarılmıştır (Tremblay 1989). Çalışma, Avrupalı turistlerden gelen turizm gelirleri üzerinde terörizmin fazla etkisinin olmadığına yönelik ortaya çıkarılan bulgular, Avrupalı turistlerin Avrupa'daki siyasi olaylarla alakalı daha iyi bilgilendirilmiş olabilecekleri ve terör olasılığının yüksek veya düşük oluşuna göre tatil yerlerini ve zamanlamalarını ayarlayabilecekleri gerçeğine bağlamıştır. Tremblay (1989), Kuzey Amerika'dan gelen turistlerden elde edilen gelirlerdeki düşüşün, genellikle terörizm şiddetinin daha çok kurbanı olmaları ve terör eylemlerinin basındaki yansımalarına daha çok maruz kalmaları sebebiyle olabileceğini belirtmiştir. Tremblay'in siyasi olaylarla ilgili daha iyi bilgilendirilen turistlerin daha yumuşak tepkiler verdiği görüşünü tekrar eden Wall (1996), Kuzey İrlanda'ya giden ziyaretçilerin, terör eylemlerinin altında yatan sebepleri bildikleri için kendilerini bu eylemler karşısında fazla tehdit altında hissetmediklerini söylemektedir. Ziyaretçilerin sayıları ve memleketleri, ziyaret edilen ülkenin turizm gelirleri ve seyahat sebepleri açısindan Kuzey İrlanda ve İrlanda Cumhuriyeti'ni karşılaştıran Wall (1996), genellikle akraba ve arkadaş ziyaretleri amacıyla seyahat edildiği için Kuzey İrlanda'nın, İrlanda Cumhuriyeti'ne göre daha az ziyaretçi aldığı ve bu ziyaretçilerin daha az para harcadığını görmüştür. Muhtemelen bu kişilerin sağladığı güvenlik ağı sayesinde bu sebeplerin, terörizm riskiyle alakalı endişelerin üstesinden gelmesi mümkündür.

Yukarıda belirtilen çalışmaların her biri yapbozun bir parçasını oluşturdukları için önemlidir. Bireylerin, tehdit altında oldukların hissettikleri zaman yaşadıkları bilişsel ve duygusal süreçleri anlamak önemlidir. Seyahatler, özellikle dinlence amaçlı olanlar, keyifli tecrübeler içermelidir. Korku veren unsurların bu denkleme girdikleri zaman, yeni tecrübelerin eğlenceli kısımları yerini korkuya bırakacaktır. Özellikle ikincil veriler kullanan araştırmalar, bu meseleleri sınırlı miktarda aydınlatabilirler. Korku ve güvenlik ihtiyacı gibi kökleri derinlere inen duyguların test edilmesi, imkânsız olmasa da oldukça zordur. İnsanların davranış biçimlerini anlamak için daha yaratıcı ve niteliksel metotlara ihtiyaç vardır. Yine de günümüze kadar yapılan çalışmalar, fazlasıyla ihtiyaç duyulan gelecek araştırmalar için bir başlangıç noktası teşkil etmektedirler.

\section{Siyasi İstikrarsızlık ve Savaş}

Şartlar büyük ölçüde değiş̧iklik gösterse de turizm; Filipinler, Tibet ve Gambiya'da siyasi bir araç olarak ortaya çıkmıştır (Tablo 1). Filipinler'deki durumun detaylı analizinden faydalanan Richter, eğer iyi bir şekilde kullanılırsa turizmin oldukça güçlü bir araç olabileceğini iddia etmektedir. Richter bu iddiasını, Filipinler'de günlük yayınlanan üç büyük gazetenin dört aylık içeriklerinin incelenmesi ile elde edilen verilerle desteklemektedir. Başkan Marcos'un 1972'de, siyasi 
karşıtlarını feshetmek amacıyla sıkıyönetim ilan etmesiyle, "yenilenmiş ve temizlenmiş bir sosyal düzen" sözü veren Yeni Toplum [New Society] kurulmuştur (Richter 1980). Marcos, sıkıyönetimin anti demokratik doğasına karşı verilen uluslararası olumsuz tepkileri başarılı bir şekilde yönetmiş ve ülkenin ekonomik gücünün uğrayabileceği zararları önleyebilmiştir. Birtakım zekice stratejiler aracılığıyla Marcos, ülkenin siyasi imajını onarmak için turizmi etkili bir biçimde kullanmıştır. Sıkıyönetimden önce Filipinler, "sözde yıkım ve şiddet ile çalkalanmakta" iken sıkıyönetimin ilanından sonra ülke, turizmin öncelikli sektör olduğu ve güvenli bir tatil bölgesi olarak lanse edilmeye başlanmıştır (Richter 1980). Turizm ile yapılan olumlu tanıtım akıllara barış ve güvenliği getirmesi dolayısıyla Yeni Topluluk, ülkeyi güvenli bir hale getirdiği için güven kazanmıştır. Richter, ülkenin olumlu imajının turizm gelirlerinden ziyade hükümet için fayda sağladığına dikkat çekmektedir. Turizmin gelişmesini gerek yurt içi gerek yurt dışında bir araç olarak kullanan Filipinler hükümeti, bu sayede itibar da kazanmıştır. Aslında, 1971'de 144.321 olan turist sayısı, 1978'de 859.396'ya yükselmiştir. Bir hükümet yetkilisi, “Filipin Tarzı Sıkıyönetim"i bir turist çekme aracı olarak ilan edecek kadar ileri gitmiştir (Richter 1980).

Turizm Tibet'te de siyasi ve farklı bir araç olarak kullanılmıştır. Mart 1989'da Lhasa'da sıkıyönetim ilan edilmesi, 1987 'de başlayan milliyetçi huzursuzlukları noktalamıştır. Tibet'te oldukça yeni olan turizm sektörü, sıkıyönetim sonucu ciddi bir darbeyle sarsılmış olsa da milliyetçi huzursuzluğun en dikkat çekici etkisi, Tibet halkının mesajlarını dünyaya duyurmak için insan hakları hakkında bilgi toplayan gizli bir turist ağının oluşmasıdır. Katılımcı-gözlemci olarak bilgi topladığ $\breve{L h a s a}^{\prime}$ da sekiz ay geçiren Schwartz, turistlerin doğasındaki değişime dair "içerden" büyüleyici ve bilgilendirici açıklamalar sunmaktadır. Schwartz bu durumu "turistin rolünün siyasallaştırılması" olarak adlandırmaktadır (Schwatrz 1991). Milliyetçi huzursuzluklar sırasında gazetecilerin ülkeye girmesine izin verilmezken Tibet'teki kaos ile ilgili tek bilgi kayna$\breve{g} 1$ turistler olmuştur. Turistler, sivillerin polis tarafından vuruldukları ve öldürüldükleri olaylara şahit olmuşlar ve bu olayları fotoğraflarla belgelemişlerdir. Bazı yabancılar fotoğraf çektikleri için tutuklanmış ve filmlerine, kameralarına ve pasaportlarına el konulmuştur. Schwartz'a (1991) göre;

... polisin meydanda, polis karakolunun önünde ateş açtığ 1 sırada turistlerin de Tibetlilerle birlikte olması, Tibetliler ile turistler arasındaki ilişkiyi fazlasıyla değiştirdi... yabancılar artık sadece gezginler değillerdi... ayn zamanda "Çin acımasızlı̆̆ının" yabancı şahitleri ve potansiyel siyasi müttefikleriydiler.

$\mathrm{Bu}$ olaylar açıça göstermektedir ki turizm, başka bir ülkedeki olaylara şahit olma fırsatı sağlamanın yanı sıra hapsedilen ve kötü davranılanlar adına bilgi toplama ve siyasi olayların yayılımı gibi politik bir araç olarak da kullanılabilir. Turizm yine başka bir ülkede daha siyasi bir araç olarak kullanıldığı ortaya çıkarılmıştır. Sharpley ve Sharpley (1995), askeri darbenin Gambiya'nın turizm sektörü üzerindeki etkilerini incelemişler ve turizm 'üreten' hükümetlerinin, turizm danışmanlarını kullanarak, turizm sektörüne bağımlı olan ülkelere karşı, siyasi güçlere sahip olmak amacıyla turist akışını etkileyebileceklerini ileri sürmüşlerdir. İddialarını desteklemek için Birleşik Devletlerin Küba ve Çin'e karşı uyguladığı seyahat yasakları ile 1980 Moskova Olimpiyatları'na karşı uyguladığı boykotu örnek göstermişlerdir. Siyasi anlamda istikrarlı bir Batı Afrika ülkesi olan (1965-94 arasında) ve kansız bir askeri darbe gören Gambiya örneğinde İngiliz Seyahat Öneri Birimi (FCO), Gambiya karşıtı birtakım sert seyahat uyarılarında bulunmuştur. Ülkenin ekonomik ve sosyal şartları, bir domino etkisiyle, hızla kötüye gitmeye başlamıştır: İngiliz ve İskandinav tur operatörleri bu ülkedeki faaliyetlerini durdurmuş, ülkeye yapılan ziyaretlerde düşüş yaşanmış, oteller kapanmış ve turizmle alakalı iş kolları yok olmuştur. Gambia Hükümetine göre, İngiltere Diş İşleri Bakanlığının seyahat önerisi “...Ordu rejimi üzerinde baskı yapmayı amaçlayan siyasi karar...", aslinda "...Resmi olmayan bir ticaret ambargosu" olarak belirtilmiştir (Sharpley ve Sharpley 1995). Bu örnek ve ABD Dışişleri Bakanı Henry Kissinger'ın Zimbabwe'ye yaptığ 1976 ziyareti sonrasında(1965-1990 yılları arasında süren 15 
yıllık özgürlük savaşı esnasında) ABD Dışişleri Bakanlığı tarafından Zimbabwe'ye karşı bildirilen seyahat tavsiyesi arasında bir paralellik elde edilmektedir. Seyahat tavsiyesinde “... Çözülmeyen durumlar, artan şiddetin potansiyeli, koruma ya da yardım sağlayacak yerel hükümetin yetersizliği..." gibi durumlardan bahsedilmiştir (Teye 1986). Tavsiye, Zambiya'nın komşuları için tasarlanmamış olduğu görünmesine rağmen, savaşın Zambiya'nın turizmi üzerindeki olumsuz etkilerini arttırdığı aşikârdır.

Bu tür düşüncesizce yapılmış ve zarar verici seyahat tavsiyelerini önlemek için, Sharpley ve Sharpley (1995) apolitik, kesin ve tarafsiz bir davranış içerisinde turistik bilgiyi toplamak, güncellemek ve yaymak için uluslararası bağımsız bir organizasyonun kurulmasını önermişlerdir. Bazı yazarlar kendi vatandaşlarını siyasi ya da çevresel olaylara karşı korumak için seçtikleri ülkelere karşı seyahat tavsiyesi yayınlamalarını her hükümetin öncellik hakkı olduklarını tartışmaktadırlar. Öte yandan, önerilen organizasyonun (muhtemelen Dünya Turizm Örgütü bünyesinde bir ajans barındırılması) kurulması, turizmin istismarını ve bazı ülkeler tarafından başkalarına karşı siyasi bir silah olarak kullanılmasını önleyebilir bir etkiye sahiptir. Alanyazın, hükümetlerin turizm yoluyla siyasi baskı uygulayabildiğini ve uygulayabileceğini ve turizmi olumlu bir imaj iletmek için tanıtım aracı olarak veya başkalarına karşı yaptırım uygulamak için kullandığını göstermektedir. Ev sahibi ve misafire trajik deneyimleri paylaşma imkânının sağlandığı Tibet örneğinde, ziyaretçilerin istek ve yetenekleri sonucunda karşılıklı güvenle Tibetlilere yardım etmelerini sağlamıştır. Turizmin siyasi gücü belirgindir, ancak olumlu ya da tehlikeli olup olmadığına bu siyasi gücü kontrol edenler karar verebilir.

Barışın, sükûnetin ve emniyetin herhangi bir bölgeye turist çekmek için gerekli olduğu inkâr edilemez bir gerçektir. Siyasi istikrar olmadan, bir ülkenin turizm endüstrisinin gelişmesi bir anlam teşkil etmeyecektir (Teye 1988). Eğer kamunun dikkati bir ülkenin siyasi meselelerine kısa veya uzun vadede yönelmişse, bu o ülkenin turizm endüstrisinin zarar göreceği anlamına gelmektedir. Siyasi problemlere değinen Scott
(1988), uzun vadeli hasar potansiyelini etkili bir biçimde şöyle vurgulamaktadır: “...Doğal bir felaket dehşet yaratır ve geçer, siyasi kriz günler, aylar hatta yıllarca sürebilir", ve bu durum gelişmekte olan bir turizm endüstrisi için kırılgan imajı tamamen yok edecektir. Bu ifade, özellikle dünya medyasında yer alan olaylar ve Çin'in 1989 yılında Tiananmen Meydanı olayında yapılan gösteri için geçerlidir. Tüm dünya, güncel haberler sayesinde, demokrasi yanlısı öğrenci protestolarına karşı hükümetin vahşiliğine tanık olmuştur. Çin'in olumsuz imajı otellerin doluluk oranlarının düşmesine ve turizm gelirinin kaybına neden olmuştur. Çin'in uluslararası ziyaretçileri çekme çabaları birkaç yıl kesintisiz durmuştur. 1991 yılında yabancı ziyarette \%55, 1992'de \%48 oranında bir artış kaydedilmiş olmasına rağmen, olay hafızalarda ciddi derecede yer edinmiştir (Hall ve O'Sullivan 1996) çünkü televizyonlara görüntü ve resimler kısa süreliğine yansımış olsa da, bıraktığı etkiler çok güçlü olmuştur.

Tüm bunların yanı sıra imaj kavramını incelediğimiz takdir de bu kavram zamansal ve mekânsal sınırların ötesine uzanıyor gibi görünmektedir. Daha önce terörizm kavramına atıfta bulunulan "genelleme etkisi" (Enders vd. 1992) siyasi sorunlar ve savaş için de geçerli bir kavramdır. 1991 Körfez Savaşı ve 1991-96 Bosna-Hersek Savaşı belirli coğrafi alanlarla sınırlı kalmıştır. Yine de bu savaşlar bu ülkelerin tüm bölgeleri için siyasi huzursuzluğu sembolize etmiştir. Basra Körfezi Savaşı sırasında Mısır, İsrail, Ürdün, Türkiye ve Birleşik Arap Emirlikleri eşit derecede etkilenmese de turist gelirlerinde belirgin bir düşüş yaşanmıştır (Hollier 1991; WTO 1991). ABD turizm endüstrisi, ticarette ve turizmde hem içe hem dişa yönelik ciddi sorunlarla karşılaşmıştır (US House of Representatives 1991; WTO, 1991). Ortadoğu'da vuku bulan terörizm ve siyasi kargaşa tehdidi, ilgili terörizm beklentileri ve tehditleri nedeniyle Çölde Fırtına Operasyonu (Operation Desert Storm) sirasinda uluslararası seyahat akışlarının büyük çapta yeniden düzenlenmesini gerektirmiştir (Hollier,1991; Abu Fadil 1992).

Balkanlar'daki (Slovenya, Hirvatistan, BosnaHersek) savaş, Yugoslavya'nın turizm faaliyeti-

Cilt $28 \bullet$ Sayı $1 \bullet$ Bahar $2017 \bullet 123$ 
ni hızlı bir biçimde durdurmuştur. Yugoslav ordusu Haziran 1991'de Slovenya'ya saldırdığında (Slovenya'daki savaş, 1991'de Hırvatistan'a ve 1992'de Bosna-Hersek'e sıçramadan önce on gün sürmesine rağmen), Yugoslavya'daki belli başl1 tur operatörleri, Mihalic'in (1996) çalışmasına göre bir milyonun üzerinde rezervasyon kaybı yaşamıştır. İki yıllık bir dönemin sonrasında bile Slovenyalıların turizm rakamları savaş öncesi rakamların çok gerisinde kalmıştır. Yazar bunu çeşitli faktörlere bağlamaktadır: Slovenya'nın Slavonya'yla (Hırvatistan'daki bölge) olan toplumsal karışıklığ ; Slovenya ya da ülkenin siyasi durumuna ilişkin bilgi eksikliği ve Slovenya'nın Yugoslavya'daki sürmekte olan savaşa olan yakınlığı gibi faktörleri ile açıklamaktadır. Görüldüğü üzere, Slovenya'nın Balkan savaşından geri dönüşü Çin'in turizme geri dönüşünden çok daha yavaş olmuştur. Hiç kuşkusuz, Boşnaklara yapılan zulmün görüntüleri insanların kolektif hafızlarında derin bir etki bırakmıştır. Slovenya herhangi bir barışçıl ülke gibi güvenli ve huzurlu bir ülke gibi algılanıyor olabilir; fakat komşularıyla ilişkilendirilen imajı savaş bittikten çok sonra bile etkisini yitirmemiştir.

Zimbabwe'de meydana gelen savaş Zambiya'nın turizm endüstrisi üzerinde ciddi derecede etkili olmuştur. Zimbabwe'nin 1965 Tek Taraflı Bağımsızlık Bildirgesinin etkilerini inceleyen Teye, Zambiya'nın turizm sektörünü zayıflatmak için Zimbabwe'de silahlı çatışma çıkardığını ortaya koymuştur. Ayrıca, bu zayıflatmanın nedeni bir takım hasar verici faktörlere dayandırılmıştır. Bunlar; turistlere ateş etme ve çocuk kaçırma eylemleri, olumsuz tanıtım, yüksek düzeyde suç algılamaları, turizm alt yapısının sistematik olarak hedeflenmesi, turistik faaliyetlerin kısıtlanması, şafak vakti gerçekleşen sokağa çıkma yasağı nedeniyle gece hayatının yok olma$\mathrm{s} 1$, turistlerin ana giriş ve çıkış noktalarına uygulanan elektrik kesintileri, askeri barikatlar, bazı alanların gerilla grupları tarafından işgal edilmesi ve fotoğraf çekimine ilişkin yasaklar gibi faktörlerdir (Teye 1986). Zambiya'ya komşu olan bölgelerde turist sayıları önemli ölçüde düşmüş ve bu da yer hizmetleri operatörlerinin turizm hizmetlerini geri çekmesine neden olmuştur. Çatışma yalnızca Zambiya'nın turizm endüstrisine zarar vermekle kalmayıp aynı zamanda turistlerin çatışma bölgelerinde korunması gibi organizasyonel ve yönetimsel problemleri de ortaya çıkarmıştır (Teye 1986).

Teye' nin (1986) yaptığı araştırma, risklerin gerçek ya da abartılı olduğuna bakılmaksızın, siyasi çatışmanın etkisinin çevresine yansıdığını ve bu dalganın etkisinin çok uzun süre turizmin farklı alanlarına yayıldığını açık bir şekilde göstermiştir. Teye' nin (1986) ihtilalcilerin genel olarak Afrika'nın turizm gelişimine ve özellikle de Gana'ya olan etkilerinin incelendiği çalışmasın$\mathrm{da}$, seyahat acenteleri potansiyel turistlere bölge önerisini durdurduğu, uluslararası turizm faaliyetlerini engellemek amacıyla sinırların kapatıldığ 1 ve turizm hizmetlerinin askıya alındığ 1 veya iptal edildiği zaman turizm faaliyetlerinin kısa bir süre durduğu sonucuna varmıştır. Teye (1986) ayrıca, bir ülkenin imajının hasar görmesi ve yabancı yatırımcıların siyasi karışıklık yaşayan ülkedeki çıkarlarını kaybettiğinde, genel turizm gelişiminin uzun vadede zarar göreceğini savunmaktadır. Çeşitli siyasi sorunların turizme bölge imajı zarar görmesi, ziyaretçilerin gelmemesi, gelirlerin düşmesi ve kalkınma planlarının rafa kalkması gibi benzer etkileri olduğu görülmektedir.

Pitts (1996) tarafından gerçekleştirilen ilginç bir çalışmada ise, turizm kalitesinin bukalemun gibi değişkenlik gösterdiğine dikkat çekilmektedir. Pitts 1994 yılında gerçekleşen silahlı isyanının Meksika hükümetine karşı etkileri hususunda pek çok turizm ögesini inceledikten sonra, yerel ve uluslararası seyahatlerde ciddi derecede düşüşler kaydedildiğini belirtmiştir. Çalışmada Pitts'ın "çatışma veya savaş turistleri" olarak nitelendirdiği San Cristobal'da yeni bir turist türü ortaya çıkarılmıştır. Bu turistlerin, eylemin bir parçası olmak ve eylemin ne olduğunu görmekle ilgilendiğini belirtmiştir. Ayrıca, Chiapas'ı bir etnik turizm ürününden, çatışma ve "siyasi şiddet heyecanı" sunan bir deneyime dönüştürdükleri ortaya çıkarılmıştır. Çalışmada ikinci bir turist grubu ise gazeteci, araştırmacı ve insan hakları savunucusu şekliyle ortaya çıkartılmıştır. Pitts (1996) birçok gezginin Meksika ordusundan ve onların bulunduğu noktalardan Zapatista dire- 
nişçilerinden daha fazla korktuğunu belirterek turist algılarında ilginç bir değişiklik yaşandığının altını çizmiştir. Muhtemelen bir turistik bölgenin sosyal, kültürel ve çevresel özellikleri turizmin etkilendiği siyasi çatışma türünden (askeri darbe, silahlı isyan ve bölgesel savaş gibi) daha güçlüdür. Bu tür ayrımlar, çözüm üretecek etkilerin derlenmesini zorlaştırmaktadır. Her bölge olumsuz imajin, azalan turizmin ve kaybedilen gelirin üstesinden gelmek için farklı zorluklarla karşılaşmaktadır. Bir ülkenin çözümleri başka bir ülke için geçerli olmayabilir; ama siyasi sorunlar veya terör tarafından harekete geçirilen turizm krizlerinden kurtulma stratejilerinin belirlenmesi gerekmektedir.

Savaş ve turizm ilişkisinin çok boyutluluğu ancak dikkatli bir değerlendirmeden sonra ortaya çıkmaktadır. İlişkinin genişliği, Diller ve Scofidio tarafından hayal gücüne dayanarak şöyle aktarılmıştır:

"Turizm ve savaş, kutupsal aşırllıklar olarak görülüyor. Bir taraftan uluslararası anlaşmanın paradigması, diğer taraftan anlaşmazlıklar. Bununla beraber iki kavram; savaşın turizmi, turizm savaşı, savaş olarak turizm, savaşı hedef alan turizm, savaş halindeki turizm gibi ilginç noktalardan en az birkaçında kesişir (Smith, 1996. 249'dan alintılandr)."

Yukarıdaki bağlantılardan birkaçından (örneğin, savaş halindeki turizm, savaş turizmi, turizm gibi savaş) söz etmek gerekmektedir. İlk ve en görünür olanı, savaşın turizm talebi üzerinde (savaş halindeki turizm) olumsuz bir etken olduğu ve turistleri daha güvenli bölgelere yönelmeye ittiğidir (Richter, 1980; Teye 1986, 1988; Mansfeld, 1995; Bar-On 1996; Mihalic, 1996; Hall ve O'Sullivan 1996). Bu, ülkenin konumuna bağlı olarak olumlu ya da olumsuz olarak değişebilmektedir çünkü daha güvenli olan ülkeler (düşmanlıklara karışmayan veya daha az müdahale eden) daha tehlikeli yerler tarafından kaybedilen ziyaretçileri kazanabilirler (Mansfeld 1995). Savaş turizmi ilişkisinin ikinci bir boyutu, çatışmanın (savaş turizmi) çekiciliğine kapılan yeni bir turist türünün ortaya çıkmasıdır (Wahab 1995; Mihalic 1996; Pitts 1996). Örneğin, bazı turistler, savaşın Hırvatistan ve Bosna'daki sonuçlarını veya neticelerini görmek isterken (Wahab 1995;
Mihalic 1996;) diğerleri ise Meksika'da ki silahlı isyana tanık olmak istemektedir (Pitts 1996). Wahab (1995), bu durumu savaş gözlemcilerini heyecan arayışında olan risk alıcılar olarak tanımlamaktadır. Savaş halinde olan bir bölgeye giden diğer savaş turistleri ise medyanın, insan hakları savunucularının ve mültecilerin (savaş turistleri) üyeleridir (Pitts 1996).

İlişkinin üçüncü bir boyutu ise, savaş anılarının duygusal bir turizm cazibesine (turizm olarak savaş) dönüşümüdür. Smith (1996) turizm ile savaş arasındaki ilginç bağlantıyı karşılaştırarak ikisini “temel ve kapsamlı grup değerleri, yaptırımları, inançları ve davranışlarının ayrılmaz bir parçası olan "sosyal süreçler" olarak ifade etmektedir.

Savaşın, turizmi savaş hali ile ilişkilendiren yer ve olaylara özel bir anlam ve anı yüklediğini belirten Smith (1996) "ölüm ve yıkımın faziletine rağmen, savaşta hatırlanmaya değer olan eşyalar ve benzer ürünler ('George Washington' un yattığ 1 evler gibi) muhtemelen dünyada en çok ziyaretçi çekenler kategorisini oluşturmaktadır" fikrini ortaya çıkarmıştır. Örnek vermek gerekirse; savaş alanları (ör. İç savaş, İkinci Dünya Savaşı); Mezarlıklar (ör., Arlington); Askerler için anıt/anıtlar (ör. Vietnam Anıtı); Düşen ateşler, madalyalar müzeleri, tarihi yeniden canlandıran ve askeri müzeler. Mihalic (1996) bir savaş sona erdiğinde "bölgede tarihsel belleğin bir parçası olur ve bu bellek turistik çekicilik haline gelir" diye belirtmiştir ve Vietnam'ın bir turizm merkezi olarak ön plana çıkması bu açıklamayı destekler nitelikte olmuştur. Benzer şekilde, savaş ünlü turistik yerleri yok ettiğinde (örneğin, eski Yugoslavya'nın ünlü bir yer olan Dubrovnik'in tahrip edilmesi), medyanın dikkati ve turistlerin ilgisi o bölgeye yoğunlaştırmak gibi bir eğilimi vardır.

Bir ülkede savaş, siyasi huzursuzluk, terörizm ya da ağır suçlar yaşanırsa, o ülkenin turizm endüstrisi ağır bir kayba maruz kalır. Normal şartlarda güvenlik tehdit edildiği zaman, güvenilir bölgeler bile zarar görmekten kaçınamaz (Richter, 1980). Düzensiz politika veya etnik ya da sosyoekonomik sıkıntıların olduğu yerlerde, turizmin güçlü ve başarılı bir şekilde gelişmesinden söz dahi edilemez; Kargaşa halinde olan ülkelere 
yakın olan ülkelerde bile aynı durumun yaşanacağ1 söylenebilmektedir (Richter 1980; Teye 1986, 1988; Bar-On 1996; Hall ve O’Sullivan 1996).

\section{Medyanın Rolü, Bölge İmajı ve Kriz Yönetimi}

Geniş çaplı siyasi tehditlere rağmen, yakın zamandaki uluslararası turizmin geçmişi bu olgunun kalıcı bir insan faaliyeti olacağını belirtilmektedir. Siyasi çatışmaların ve terörizmin aynı seviyede süreceğine yönelik yeterli sebep bulunamadığı için, ilişkileri yönetmek adına çeşitli stratejilerin geliştirilmesi önem teşkil etmektedir. Endüstri üzerindeki şiddet ve siyasi bozulmanın etkileri kriz olarak değerlendirilmedir. Açıkça görülmektedir ki, turizm geleneksel pazarlama ilkelerini kullanmada oldukça başarılı bir sektördür. Ancak, sektör olumsuzluklardan dolayı ciddi bir gerileme yaşamaya maruz kalırsa, artık geleneksel pazarlama çalışmaları işlevini kaybedecektir. Sektör, kriz yönetimi faaliyetleriyle tamamen bütünleşmiş "pazarı iyileştirme" ya da "yeni pazarlama" faaliyetlerini iyi bir şekilde yürütmelidir. Bu makalede atıfta bulunulan destinasyon imajı, şiddetten ilk etkilenen olması nedeniyle turizmin kriz yönetimi ve piyasanın canlanmasını en çok gerektiren kısmıdır.

İmaj, "basitleştirilmiş gösterimler" (Mayo 1973), "bir varlığın diğerlerinin zihninde yaptığı toplam izlenim" (Dichter 1985) ve "insanların ellerinde bulunduğu nesneler, davranışlar ve olaylara yönelik sahip olduğu inanç, izlenim, fikir ve algiların toplamı" olarak tanımlanmaktadır (Crompton 1979). İmajın organik (gerçek deneyim veya ziyaret sonucunda dahil olunarak oluşturulan) ve yapay (reklamlar, tanitım, haberler ya da tanıdıkların tavsiyeleri gibi harici olarak alınan ve işlenen bilgiden oluşturulan) olmak üzere iki düzeyde geliştiği vurgulanmaktadır (Gunn 1972; Gartner 1989). Terörizmin ya da siyasi karışıklıkların medyada ele alınması, kişilerin bölgeye olan yapay imajını şekillendirme potansiyeline sahiptir. Medyanın önceden var olan tutumları değiştirme gücü kısmen incelenmiştir. Ancak Weimann ve Winn (1994), medyanin tam olarak oluşmamış tutumları etkileme becerisi olduğunu şu şekilde savunmaktadırlar:
Terör olaylarının özellikle medyada yer alması, güçlü bir potansiyel etkiye sahiptir çünkü medya herhangi bir konuda kitlelerin sıklıkla başvurduğu tek kaynaktır. Medya sadece sıklikla başvurulan eşsiz bir bilgi kaynă̆ı değil ayn zamanda benzersiz bir yorum kaynă̆ı olarak da görülebilir. Özellikle, halk teröristlerin güdülerini, eylemlerinin sonuçların ve durumun temel özelliğini anlamak için medya beyanlarına muazzam bir güven duyma eğiliminde olmaktadır.

$\mathrm{Bu}$ açıklama, teröristlere ve teröristlerin amaçlarına yönelik tutumlarına değinmektedir ancak halkın çok fazla bilgi sahibi olmadığı bölge imajına da uygulanabilir. Medyada yer alan olumsuzluklar kişilerin destinasyona yönelik tutum oluşumunu oldukça kolay bir şekilde etkilemektedir. Turistik deneyimin somut doğası nedeniyle, bölgeler olumlu imajlara büyük ölçüde bel bağlamaktadır. Sonuçta, imaj turizm pazarlamasında ve seyahat yeri seçiminde önemli bir faktördür (Chon 1991; Echtner ve Ritchie, 1991; Gartner, 1993; Bramwell ve Rawding 1996; Dann, 1996). Karar verme süreci boyunca, potansiyel turistler bölgeleri algilanan maliyetler ve sağladığ 1 faydalara göre karşılaştırmaktadırlar (Van Raaij ve Francken, 1984; Woodside ve Lysonski, 1989; Enders ve Sandler, 1991; Crompton 1992; Enders, Sandler ve Parise 1992). Bazı alternatif bölgeler terör tehdidi veya siyasi kargaşa imajıyla medyada yer alırsa maliyetler ya da algılanan risk sonucunda potansiyel ziyaretçiler tarafından elenebilmektedir. İyi pazarlanmış olsa bile imajın önemi, terörizm ya da politik kargaşanın bölge imajı üzerindeki etkisi (Witt ve Moore, 1992) ve kitle iletişim araçlarıyla olan ilişkisi (Ehemann, 1977; Butler 1990) yeteri kadar araştırılmamıştır.

Sivil kargaşa ve terörizm üzerinden yaratılan olumsuz imaj üzerine yapılan bir çalışmada Witt ve Moore (1992), Kuzey İrlanda'nın olumsuz diş imajına daha ağır basan belli olayların yeterli turistik ilgi yaratıp yaratmadığını araştırmışlardır. Araştırmacılar bir bölgenin terörizmden kaynaklanan olumsuz izleniminin üstesinden gelmek için daha fazla dikkatin gerekliliğini ifade etmişlerdir. Ancak, olumsuz imajların üstesinden gelmek için çözümler üretmek yerine, ziyaretleri arttırma stratejilerini önermektedirler (diğer bir deyişle dikkatin başka yöne aktarılması için ye- 
ni turizm ürünleri geliştirmek). Belirli olayların tek başına sahnelenmesinin yeterli olmayacağı, aynı zamanda bu çabaların önemli tanıtımlarla desteklenmesi gerektiği ayrıca belirtmişlerdir. Butler (1990), imaj oluşumu üzerinde üç medya türünün (sözlü, yazıll, görsel) etkisini tarihsel bir perspektiften tartışmaktadır; ancak kitle iletişim araçlarının bölge imajı üzerindeki etkilerini incelememektedir. Daha önce yapılan bir çalışmada, İrlanda Cumhuriyeti'ndeki basılı medyada yer alan olaylar kelime kullanımı bakımından incelenmiştir (Ehemann 1977). Yazar, Brookfield'in (1969) bireylerin edindiği bilgi türü ile algılanan çevre sınıflandırmasına yani Günlük deneyim (net ve doğru); Gölge bölgesi (bireyin o anki alanının ötesinde bulunan az rastlanan veya ikincil deneyim); ve dış alan (ikincil bilgi kaynaklarına bağlı) atıfta bulunmaktadır. Buna göre, bir bölgenin medyada olumsuz bir şekilde yer alması, potansiyel gezginler tarafından algılanan çevrenin dış alanına da etki edebilmektedir. Ethemann (1977) bir bölgeye ilişkin değer yargısı taşıyan ve bu bölgenin olumsuz değerlendirilmesinde payı olan basılı medya aracılığıyla kullanılan (örneğin, İrlanda çok çalkantılı bir ülkedir gibi) değer yüklü ifadelere karşı çıkmaktadır. Ehemann'ın (1977) “davranışlar algılanmış dünyaya yöneliktir, ancak bu davranışlar çarpıtılmış olabilir" ifadesi, iletişim araçlarının kamusal algı üzerindeki gücü ve algıların birçok birey için gerçekliği temsil ettiği gerçeğini ima etmektedir. 28 milyon Amerikalı yurtdışına çıkması ve 162 'sinin terör eylemlerinde öldürülmüş ya da yaralanmış olması bu durumu örnekler niteliktedir. Bu durum ayrıca terörizmden zarar görme olasılı̆̆ının $\%$ 0,00057' den daha az olası bir ihtimal olduğuna işaret etmektedir. Olasılığın düşük olmasına rağmen, 1,8 milyon Amerikalı 1986'da önceki yıl gerçekleşen denizaşırı seyahat miktarının yaklaşık \%6,43'üne eşit olan terör olayları nedeniyle yurtdışında gerçekleştirmek istedikleri seyahat planlarını değiştirmişlerdir.

Kitle iletişim araçları ile teröristler arasındaki karşılıklı dayanışmanın incelendiği araştırmada, Weimann ve Winn (1994) kitle iletişim araçlarının halkın algılamaları üzerinde etkisi olduğunu vurgulamaktadırlar. Terörle ilgili üç ayrı veri setinin kapsamlı analizinin incelendiği çalışmada
(1968 ve 1986 yılları arasında RAND Corporation tarafından geliştirilen terör olaylarının kronolojisi; $\mathrm{ABC}$, $\mathrm{CBS}$ ve NBC televizyon şebekelerinin Vanderbilt Arşivlerinden haberleri; Birleşik Devletler, Kanada, Fransa, Almanya, İsrail, Misır ve Pakistan'ın dokuz uluslararası gazetesinin terörle ilgili içerikleri) Weimann ve Winn, teröristler ve gazeteciler arasında simbiyotik bir ilişki olduğunu ortaya koymuşlardır. "The Theater of Terror: Mass Media and International Terrorism (1994)" adlı çalışmalarında terörizmin hem sembolik bir olay hem de medyanın dikkatini çekmek için sahnelenen bir eylem olduğunu belirtmektedirler. Karber'in (1971) iletişim aracı olarak terörizm tanımı Weimann ve Winn (1994)' in sahte olaylar olarak terörizm tanımına yeni bir anlam kazandırmaktadır. Yayın araçları (özellikle televizyon), terör olaylarının dikkat çeken eylemleri için mükemmel bir sahne sağlamaktadır. Farklı nedenlere rağmen garip bir şekilde, medya ve teröristler izleyici ile iletişim kurmak için birbirlerine yardım etmek üzere bir araya gelmektedirler; Medya daha yüksek reytingler elde ederken teröristler tanınma hedeflerine ulaşmaktadır. Frederick Hacker (1994) (davranışsal uzman ve Avusturyalı-Amerikalı psikiyatrist) bu ilişkiyi "Kitle iletişim araçları isteyerek ya da istemeyerek teröristlerin savunucusu, terörün verdiği mesajlarının aktarıcısı, bütün önemi, heyecanı ve dramasiyla terör eylemlerinin izleyiciye iletilmesini sağlayan bir aracı olmuştur" diyerek kısaca açıklamıştır. Ayrıca, Frederick Hacker bu yolla bu tür grupların Medya gündemini günler veya haftalar boyunca meşgul ederek görünürlüklerini artırmayı ve mesajlarını daha detaylı biçimde yaymayı; nispi ahlaki meşruiyetlerini arttırmayı ve örgütsel etkinliklerini geliştirmeyi umut edebileceklerini belirtmiştir.

Sadece medyanın ilgi alnına girmek, dikkat çekmek isteyen teröristler için tatmin edici bir durum olsa da, yine de tatmin düzeyleri medyada yer almaları sonucu edindikleri somut faydalara dayanmaktadır (diğer bir deyişle, halk tarafından tanınmalarının artması, rakip terörist gruplarına hâkim olmak, siyasi hedeflere yaklaşmak) (Federick Hacker 1994). Teröristlerin turizmi akamete uğratma nedenleri göz önünde bulundurulduğunda, turistleri hedef alan şidde- 
tin medyada yer alması terörist gruplarına son derece tatmin edici gelmektedir. Terörist-medya ilişkisinin karşılıklı ve bağımlı ama tuhaf doğasinı incelemeye devam eden Weimann ve Winn, bir terör olayıyla ilgili medyayı ilgilendiren faktörleri tartışmaktadırlar. 13 koşulun (Galtung ve Ruge 1965) karşılandığında, olaylar televizyonda yayınlanmaktadır. Yerine getirilmesi gereken bazı koşullar; olayların sıklığı haber üretiminin sıklığı ile uyumlu olmalı (terör olaylarının yoğunluğu, kısa süreli ve hızlı olması doğal olarak yavaş yavaş ortaya çıkan olaylara tercih edilir); Terör olayı, bir olayın televizyonda yer alması için gerekli duygusal öneme sahip olmalı; eylemin kendisi açık, anlaşılır ve rapor edilmesi kolay olmalı; olay genellikle izleyicinin kültürel çerçevesinde anlamlı olmalı (özellikle yabancı turistler söz konusu olduğunda); olay dünyanın birçok ülkesiyle ilgili olmalı ve genellikle beklenmedik ve sürpriz bir unsuru bünyesinde barındırmalıdır. Bu koşullardan yola çıkarak, terör olayları medya yayın için ideal bir konu gibi görünmektedir; Medya, teröristlere kendi seslerini duyurabilecekleri nihai aracı vermektedir. Sinn Fein (IRA siyasi kanadı) başkanı Gerry Adams'ın yaptığı bir açıklama her şeyi açıkça ortaya koymaktadır:

Silahlı mücadele taktikleri çok önemli bir noktada durduğundan hayati öneme sahiptir. Bu olmadan Irlanda meselesi bir sorun bile olamaz. Böylece silahl mücadele silahlı propaganda haline gelecektir (Weimann ve Winn 1994).

Medya ve teröristlerin karşılıklı olarak girmiş oldukları ilişkinin taraflar için sağladığı ortak faydaları aşikârdır. Ancak eksik görünen şey medya üyelerinin daha yüksek reytingler uğruna terör faaliyetlerinin hedeflerini karşılamak için almış oldukları kararlarındaki sosyal sorumluluktur. Medyanın terörizmi kendi kapsamına almasına ilişkin bir diğer ve daha kışkırtıcı açıklama Chomsky ve Hermann'a atfedilmektedir:

...Kitle iletişim araçları terörizme abartılmış bir ilgi göstermekte ve gerçekliğin bu şekilde çarpıtılması Birleşik Devletlerin halkın dikkatini asıl terörizmden başka yöne çekmek için kullandığı stratejiyi ve Amerika ve Üçüncü Dünya Müttefikleri tarafindan uygulanan kasıtlı şiddeti yansıtmaktadır. (Weimann ve Winn 1994).
Batılı ülkelerinin dikkatleri devlet destekli terörizmden uzaklaştırmak için bazı terörizm türlerini (yani Batı karşıtı terör örgütleri tarafından) öne çıkardığı eleştirel görüşü gerçekten rahatsız edicidir. Nedenlerine bakılmaksızın, teröristlere tanınan süre ve özen, hem örgütlerine hem de medyaya açıkça fayda sağlamaktadır. Bu durumda kaybedenler genellikle toplum ve olumsuz imaja sahip olacak olan bölgelerdir.

Terörizmin sonuçlarından farklı biçimlerde korunabilmek mümkündür. Yalnız seyahat eden turistler bazı kaynaklar sayesinde güvenlik ipuçlarına erişebilirler. Popüler seyahat dergileri ve diğer çeşitli süreli yayınlar, terörizm, siyasi karışıklıklar ve sağlık sorunları ile ilgili önleyici veya uyarıcı tedbirlerin anlatıldı̆̆ yahatlerin tehlikelerini açıklamaktadır. (Reeves 1987; The Economist 1986a, b, 1990; Norton 1991; Chandler 1991; Englander 1991; Fedarko 1993; Fletcher 1993; Hagerty 1993). Ayrica, akademik dergilerde seyahat güvenliği konularına odaklanan makaleler de bulunmaktadır (Lehrman 1986; Ryan 1993; Skolnik 1991).

Bilginin ulaşılabilirliği ve uygulanabilirliği göz önünde bulundurulduğunda, turistler genellikle kendilerinden sorumludurlar; Bireyler kendi kararlarını vermeli ve buna göre hareket etmelidir. Risklere rağmen seyahat etmeye karar verenlere bazı koruyucu stratejiler önerilmektedir. D'Amore ve Anuza (1986), uluslararası turistler için kriz yönetimini ilk kez ileri süren araştırmacılar arasında yer almaktadır. Örneğin, bu kişilere zenginliklerini sergilemekten kaçınmaları, düşük bir profil çizmeleri, uzun iş gezileri boyunca günlük rutinlerini değiştirmeleri ve ekonomi sınıfında uçmaları önerilmektedir. Eğer gezinin potansiyel maliyetleri elde edilebilecek olan faydaları aşarsa, turistler evde kalmaya karar vermektedirler. Maalesef, terörizm ya da siyasi kargaşadan mustarip olan bölgeler için çözümler basit görünmemektedir. Özellikle ekonomik istikrarları turizme bağlıysa, bu konuyu, yönetilmesi gereken bir kriz gibi ele almaktan başka seçenekleri yoktur. Terörizm, turizm endüstrisi tarafından bir kriz olarak görülebiliyorsa, endüstri enerjisini ve ilgisini etkin bir şekilde yönetebilmelidir. Turizm için kriz yönetimi ihtiyacı 
bu kadar açıkken, pek az çalışma bu konuyu ele almıştır (Sönmez vd. 1994, Wahab 1996; Waugh 1990). Açıklamak gerekirse, kriz “...Olumsuz bir tanıtım ve tam bir iyileşme gösterene kadar ve felaket öncesi döneme geçinceye kadar bir felaketin meydana gelmesinden sonra meydana gelen olay..." olarak tanımlanmakta olup; felaket "Ani yaşam kayıplarına, insanların acı çekmesine, kamu ve özel mülkün hasarına, ekonomik ve sosyal bozulmaya neden olan bir olay" olarak tanımlanmaktadır (Sönmez vd. 1994 ).Turizm krizi ise; Turizmle ilgili işletmelerin normal işeyişini ve yönetimini tehdit eden; Bir turistik bölgenin, bölgeye yönelik ziyaretçilerin algılarını olumsuz yönde etkilemek suretiyle güvenlik, çekicilik ve rahatlık konusunda genel itibarın zedeleyen ve dolayısıyla yerel seyahat ve turizm ekonomisinde bir düşüşe neden olan ve turistlerin gelişi ve harcamalarını azaltılarak yerel seyahat ve turizm endüstrisi için işletme faaliyetlerinin sürekliliğini durduran her türlü olay olarak tanımlanmıştır (Sonmez, vd. 1994).

$\mathrm{Bu}$ durumdan şu sonuç çıkarılabilir; turistik faaliyetleri tehdit eden kriz durumları genellikle kısa süreli felaketlerle (insan kaynaklı ya da doğal) başlamaktadır. Bundan dolayı, eğer bir bölgenin güvenlik imajı önemli ölçüde zarar görürse, bir tek terör olayı (bir felaket başlangıcı olarak görülür) ya da tekrarlanan saldırılar kriz durumu yaratabilir (ör: Misır, Peru ve İspanya) (Wahab 1996). Bölge, sadece krizi yönetmekle kalmayıp, olumlu imajinı yeniden kurarak zarar görmüş turizmi kurtarmak için yeni pazarlama çabalarına başlamalıdır.

Terörizmin tetiklediği turizm krizleri, doğal felaketlerden kaynaklanan krizlerden farklı olabilmektedir ancak genel turizm krizlerini yönetmek için sunulacak öneriler bellidir. Kriz durumlarının üstesinden gelmek için öncelikle (herhangi bir olumsuzluktan önce) medya, halkla ilişkiler, bilgi koordinasyonu, fon toplama, pazarlama ve reklamcılık ile ilişkili olan grupları yetkilendiren ekibin kurulması önerilmektedir. Daha sonrasında, bir durumun kriz olarak doğru şekilde tanımlanmasıyla birlikte kriz yönetimi faaliyetlerine başlanması önerilmektedir. "Kriz zihniyetini" hazırladıktan sonra, durumun ağırlığı, tam iyileşme gösterene kadar disiplin ve bağlıkla sürdürülmelidir. Diğer öneriler arasında basın toplantılarının düzenlenmesi, dengeli ve doğru yayınlar yapılmasının sağlanması için medya ile güçlü bir ilişki geliştirilmesi ve medya dağıtımı için basın setlerinin geliştirilmesi yer almaktadır (Sönmez vd. 1994). Bu öneriler aslında kriz yöneticilerini piyasa iyileştirmesini uygulamak için yönlendirmekte olup, bölgenin kaybolan imajını onarmaktadir.

Mısır'ın teröre karşı aynı şekilde cevap vermesinden yola çıarak (Tablo 1), Wahab (1996), güvenlik ve tanıtıma dayanan turizm krizini yönetmek için atılabilecek adımları anlatmaktadır. Misır polisi terörist liderlerini bulup yakalayarak önleyici ve proaktif önlemleri hayata geçirmiştir. Teröristlerin uluslararası turistleri hedeflemesi sonrasında, ülkenin polis teşkilatı ülkeyi ve özellikle savunmasız turizm endüstrisini korumayı amaçlayan katı cezai yaptırımlara dayanan terörle mücadele önlemlerini kabul etmişlerdir. Bu kapsamda her otobüste, trende ve turist taşıyan Nil kruvazöründe "ihtiyatlı" bir polis koruması bulundurmuşlardır. Mısır'daki kriz yönetiminin bir başka yönü de sert tanıtımlar olmuştur. Bakanlık, yoğun pazarlama dâhil yeni hedefler belirlemeden önce mevcut pazarlama stratejisini yeniden değerlendirmiş ve bu zayıf imajın üstesinden gelmenin tek yolun (terörizmle sonuçlanan) uluslararası medyanın dikkatini çekmek için yeterli cepheyi sağlayacak güçlü tanıtımlar yapmaktan geçtiğinin üzerinde durulmuştur (Wahab 1996).

Olumlu bir tanıtım yapmak ve dünya ve endüstrinin ilgisini çekmek için Mısır, terörizmden uzak bir dizi uluslararası özel etkinliğe ev sahipliği yapmıştır. Salt tanıtımın yetersiz olduğunu kabul ederek, Wahab (1996) ayrıca uluslararası medya mensuplarıyla iyi temasların sürdürülmesini önermektedir. Uluslararası tur operatörlerine, seyahat acentelerine ve basina (seyahat risklerini uygun bağlamda değerlendirmek için) kapsamlı bilgi sağlamayı ve her ihtimale karşı yüksek riskli alanların rehberlerle beraber gezilmesi gerektiğini önermiştir. Yine, Meksika Chiapas'daki (Tablo 1) çatışma sona erdikten sonra, yeni turizm bakanı tarafından sert bir biçimde 
toparlanma çabaları uygulanmıştır. Bütün faaliyetler, Chiapas'a olan güvenin yeniden kurularak iç turizmi artırma çabalarıyla bütünleşmiştir. Bu bağlamda, Meksika'daki işletmelere, toplantılarını ve konferanslarını şehrin yeni kongre merkezlerinde yapmaları için bir milyon mektup gönderilmiştir ve teşvik olarak, işletmelere Chiapas otellerinde vergi indirimi teklifi sunulmuştur. Ayrıca otel fiyatları daha rekabetçi seviyelere kadar indirilmiştir. Pitts (1996) bunlara ek olarak benzer bir kadere maruz kalan diğer bölgelerin, videolarını çekip dağıtarak barış ve istikrar kazanmayı ve iyileştirme çabalarına yardımcı olmak için aynı etkiye sahip slogan geliştirmeyi önermektedir.

Terörizmin çok yakın bir zamanda sona ermesi beklenen vahşi bir eğilimden çok daha fazlası olduğu açıktır. Ama dünyadaki terör veya siyasi kargaşadan mustarip olan çok az ülke turizm gelirlerinden vazgeçmeyi göze almaktadır. Bunun yerine, olumsuz olaylarla başa çıkmak için stratejiler geliştirmektedirler. Terörizm ve turizm arasındaki ilişkinin anlaşılması, belki de ilk adımların başında gelebilir. Terörizmi tamamen kontrol etmek zor (hatta imkânsız) olabilir, ancak ülkeler bu sorunu görmezden gelemezler. Hem devlet yetkilileri hem de turizm endüstrisi, uluslararası turistlerin risk durumlarını ve etkin kriz pazarlama stratejilerini değerlendirmek için bu tehdide odaklanmalıdır (Hall ve O'Sullivan 1996). Çoğu krizin önlenmesi, terörizm ya da siyasi kargaşaların öngörülememesi nedeniyle zordur. Dahası, her kriz durumu basit formüller ile çözülemeyecek kadar farklı ve zordur. Bölgelerin ihtiyaçlarına özel bir eylem planı hazırlaması şarttır. Bir bölge kriz ile karşılaştığında, olası bir plan önemli ölçüde zaman, enerji ve diğer kaynakları korunmasına yardımcı olacaktır. Toplumsal ve küresel karmaşıklıklar göz önünde bulundurulduğunda, hiçbir bölge negatif durumlardan muaf değildir; bu yüzden "bize bir şey olmaz" felsefesi pervasiz ve profesyonellikten uzaktır.

\section{SONUC}

Son 25 yılda vuku bulan olayların üstünkörü incelenmesi bile, terörizmin bir anda bitmeyeceğini göstermek için yeterli olmuştur. Terörizmin kalıcılığını, bölgesel ve siyasi problemleri kabul etmek ve onları idare etmek bir zorunluluktur. Bu durum sadece terörizmden veya siyasi rahatsızlıklardan etkilenen ülkeler ile turizm üreten ülkeler için değil, aynı zamanda uluslararası turizm endüstrisi için de geçerlidir. Endüstri doğal felaketlerden kaynaklanan olaylar yaşadığ 1 zaman, halkın ve endüstrinin anlayış ve hoşgörüsüne başvurulur. Fakat insan kaynaklı olaylar, özellikle siyasi şiddet içeren olaylar, halkın öfke veya korkusunu tetiklemektedir. Eldeki sorun son derece karmaşık olmasına rağmen, etkin ve uygulanabilir çözümler için umut, sanayi uygulayıcılarının, devlet kurumlarının ve akademik kurumların ek araştırma ve işbirliği çabalarında yatmaktadir.

Bu çalışma, turizm kapsamında siyasi istikrarsızlığın ve terörizmin arka planını sunmaya çalışmıştır. Kayda değer ve oldukça kapsamlı çalışmalara yönelik farklı alanlardan yazarların katkı sunduğu alan yazın bilgisi çalışmada sunulmuştur. Bu çalışmanın kopyalanmaktan ziyade ileriki araştırmalar için temel oluşturması beklenilmektedir. Örneğin, turist gelişlerine, yapılan harcamalara ve seyahat akışının yeniden düzenlenmesine odaklanan çalışmalar yararlı olabilmektedir; fakat terörizmin ekonomik kayıplara yol açması sonucunda insanlar birbirlerini desteklemekten çok daha fazlasını yapmaktadır. Küçük farklılıkların dışında, araştırmacılar, siyasi şiddetin herhangi bir biçimde bölge imajına ve dolayısıyla turist akımlara zarar verdiği konusunda ittifak etmişlerdir. Bu durum sağlandığına göre, araştırmacıların terörle mücadele için olası çözümleri ve önleyici tedbirleri araştırmaları gerekmektedir. Bu yazıda değinilen birçok çalışma kriz yönetimi çalışmalarının yapılması gerekliliğini savunmakla birlikte, pek azı bu mücadeleyi ele almıştır. Bunun nedeni, yapılması gerekenin oldukça ağır olması, terör kaynaklı bir krizi yönetmenin ürkütücü olması ve bölgeye yeniden imaj kazandırmanın zor bir konu olması olarak değerlendirilebilir. Konuya odaklanan faydalı çalışmalar olmasına rağmen, ek araştırmalara gereksinim olduğu aşikârdır. İleriki çalışmalar için olası konular aşağıdaki tabloda verilmiştir. 
Tablo 2. Turizm ile Terörizm veya Siyasal İstikrarsızlık İlişkisine Odaklanan Araştırmalar

\begin{tabular}{ll}
\hline Kaynak & Konu / Baş̧ıca Bulgular / Sonuçlar \\
\hline Richter (1980) & Filipinler'de önde gelen üç gazetenin dört aylık içerik analizi yapıılmıştr. Cumhurbaşkanı Marcos 1972'de \\
& "Yeni Topluluk-New Society"yi ortaya attğında düzeni sağlamak için sıkıönetim ilan etmiştir. Sıkıyönetim \\
& bildirgesi, ülkeyi "güvenli bir bölge” olarak pazarlamayı sağlamış ve turizm endüstrisi, Yeni Topluluğun ülkeyi \\
& güven altına alması için katkıda bulunmasına neden olduğu ortaya çıkarılmıştr. Yazar, turizmin siyasi bir araç \\
& haline geldiğini ileri sürmekte ve siyasi istikrarın başarııı bir turizm faaliyeti için ön koşul olarak önemli doğal ve \\
& kültürel cazibe merkezlerinin ötesine geçtiği sonucuna varmıştı.
\end{tabular}

Richter (1983) C Çalışmada terörizm ve turizm arasındaki ilişkiler tartısıılmış ve huzurlu bir seyahat ile diplomatik ilişkiler arasındaki paralellik gösterilmiştir. Yazar, çalışmada turistleri, teröristler için yararlı hedefler olarak tanımlamaktadır.

D’Amore and Terörizmin uluslararası seyahatler üzerindeki etkileri, terörizm tehdidine yönelik gezginlerin tepkileri, pazarlama Anuza (1986) faaliyetlerinin etkileri, bireyler ve turizm endüstrisi için güvenlik konuları ele alınmıştır. Araştırma sonuçları, daha deneyimli turistlerin terörizmi, tecrübesiz ve endişeli olanlara kıyasla daha doğal karşıladıkları sonucuna v arılmıştır.

Richter and Teröristlerin amaç ve hedeflerinin sınıflandırılması, turistlere/turizme yönelik saldırıların, endüstriyi kontrol Waugh, Jr. (1986) eden sosyoekonomik ve politik seçkinlere karşı olan saldırılardan daha fazla ses getirdiği sonucuna ulaşılmıştır.

Teye (1986) Z Zimbabwe'nin Tek Taraflı Bağımsızık Bildirgesi'nin (UDI) Zambiya'nın turizm endüstrisi üzerindeki etkileri tartışılmaktadır. Zimbabwe'nin kurtuluş savaşı, bölgedeki turizmi etkilemiştir. Tur operatörlerinin bölgeden çekilmesi, turistlerin kaçırılması ve üzerlerine ateş açılması, olumsuz tanıtım, belli belirsiz hedefler olarak turizm altyapısının seçilmesi, turistik faaliyetlerin kısıtlanması, sokağa çıkma yasakları, fotoğraf çekiminin yasaklanması ve ABD Dışişleri Bakanlığı'nın seyahat uyarısı sonucunda Zambiya'nın gelen turist sayısında düşüş yaşanmıştir.

Brady and Avrupa turizmine olan talebi belirlemek ve 1986 yaz turizminde çeşitli olayların (ör. Terörizm, Çernobil, ABD’nin Widdows (1988) Libya'ya baskını) etkilerini tahmin etmek için tüketici talep analizi yöntemleri uygulanmıştır.

Conant,

Clark, Burnett

and Zank (1988)

Posta anketi aracılığıyla 359 adet en büyük ABD seyahat acentesinin 1986 yılında yaşanan terör krizine verdiği yanıtların ampirik çalışması yapılmıştır. Katlımcılardan terör tehdidinden yola çıkarak pazarlama stratejilerini açıklamaları ve terörizmin etkilerini en aza indirgemede 16 rekabetçi pazarlama stratejisi unsurlarının önemini değerlendirmeleri istenmiştir. Sonuçlar, tanıtım, halkla ilişkiler ve kişisel satışların terör yönetiminde önemli rol oynadığını göstermektedir.

Hurley (1988) Çalışma 1985 ve 1986 yılında Roma’ya gelen yabancı ziyaretçilerin karşılaştırmasını ele almaktadır. Ayrıca, 80’li yılların ortalarında terör olaylarından sonra otellerdeki doluluk oranlarını incelemiştir. Bulgular, Roma'daki 4-5 yıldızlı oteller için Roma'ya gelen Amerikalı ziyaretçilerin \%59’un üzerinde azaldığını ve doluluk oranlarının \%37’nin biraz altına düştüğünü göstermektedir. Yazar, Amerikalı turistlerin "kararsız" olduğunu ve Amerikan ticaretine bağımlı otellerin de pazarlama vurgusunu Avrupa ve Asya turistlerine kaydırılması gerektiği belirtmiştir.

Scott (1988) Yazar, 1987'de 2 ay içinde 2 askeri darbe sonucunda turizmin kötüye gittiği Fiji ada ülkesini örnek olay kapsamında incelemiştir. Avustralya ve Yeni Zelanda tarafindan verilen seyahat tavsiyeleri, Fiji'nin uluslararası havaalanında Air New Zealand Boeing 747'yi kaçırma girişiminde bulunulması ve medyanın durumu şiddetlendirmesi ile turizmde gerileme yaşanmıştır.

Hartz (1989) C Çalışmada kurul onaylı psikiyatrist tarafindan ABD’li çok uluslu 4 şirketten yurtdışına sürekli seyahat eden 29 üst düzey işletme yöneticisi ile derinlemesine görüşmeler yapılmıştır. Araştırmaya göre \%66'sı kaçırıldıklarını \%31'i ge çek terör olaylarının kurbanı olduklarını, \%8 'inin terör olaylarından kıl payı kurtulduğu ve \% 83'ü ise davranışlarının daha güvenli davranışlara yöneldiğini belirtmiştir.

Tremblay (1989) 18 Avrupa ülkesinin ikincil verileri olan turizm gelirleri toplanarak incelenmiştir. Tabi tutulan regresyon analizinde kazançlar bağımlı değişken, terör faaliyeti, ulaşım maliyetleri, döviz kurları, nisbi fiyatlar ve gelir bağımsız değişken olarak tanımlanmıştır. Terörizmden ciddi derecede etkilenen Kuzey Amerikalı turistlerden elde edilen kazançların aksine, terörizmin Avrupalı turistlerden elde edilen kazançlar üzerinde önemli bir etkisinin olduğu bulunamamıştır.

Cook, Jr. (1990) Terörizmin, suçun ve siyasi istikrarsızlığın iş amaçlı seyahat eden 408 kişilik bir turist grubunun uluslararası yolculuk yapma isteği üzerine olan etkilerinin ampirik çalışması yapılmıştır. Bir uluslararası güvenlik konferansına katılan 140 kişiye, varsayımsal durumlarla anket uygulanmıştır. İkinci aşamada, 268 yöneticiye anket yapılmıştr. Veriler regresyon ve ANOVA kullanılarak analiz edilmiştir. Sonuçlar, uluslararası seyahat istekliliğinin önceki tecrübelere paralel olarak arttı̆ını göstermiştir. Katılımcıların suçtan korktuğu fakat terörizm konusunda daha endişeli olduğu sonucu ortaya çıkarılmıştır. Siyasi istikrarsızlığın, terörizm ile birlikte olmadığı sürece ciddi bir endişe yaratmadığı görülmüştür.

Hollier (1991) Yazar, Pers Körfez Savaşının turistik faaliyet üzerindeki etkilerini incelemiştir. Körfez Savaşı sırasında Mısır, İsrail, Ürdün, Türkiye ve Birleşik Arap Emirlikleri turist gelirlerinde belirgin bir düşüş yaşamış ve "Desert Storm Operasyonu” sırasında uluslararası seyahat akışlarının büyük çapta yeniden düzenlenmesine neden olmuştur. 
Tablo 2. Turizm ile Terörizm veya Siyasal İstikrarsızlık İlişkisine Odaklanan Araştırmalar (Devam)

\begin{tabular}{|c|c|}
\hline Kaynak & Konu / Başlıca Bulgular / Sonuçlar \\
\hline Schwartz (1991) & $\begin{array}{l}\text { Yazar, sıkıyönetim sırasında Tibet bölgesini örnek olay kapsamında (1989'da Lhasa'da ilan edilen) ve turist-ev sahibi } \\
\text { ilişkisinin müteakip dönüşümünü incelemiştir. Turistler, polisin mesajlarııı dışarıya iletmek için çağrıda bulunan } \\
\text { sivilleri vurduğuna ve öldürdüğü tanık olmuş ve fotoğraflarını çekmişlerdir. }\end{array}$ \\
\hline $\begin{array}{l}\text { Enders, } \\
\text { Sandler ve } \\
\text { Parise (1992) }\end{array}$ & $\begin{array}{l}\text { 1968-1988 yılları arasında Avrupa kıtasında yer alan } 12 \text { ülkede, terörizmin turizm üzerindeki etkilerini incelemek } \\
\text { için ikincil veri kaynakları kullanılımıştr. Turizm pazar payları, ülkeye/bölgeye yönelik terörist saldırıların zaman } \\
\text { serilerine dayanan bir aktarım işlevi ARıMA Modeli kullanılarak tahmin edilmiştir. Terörizmin ekonomik maliyeti, IMF } \\
\text { tarafindan bildirilen turist gelirlerinin değeri ile temsil edilmiştir. Araştırmada, bir ülkenin komşusunda terörizm olayı } \\
\text { yaşandığında bir diğer ülkeyi de etkiliyorsa bu "genelleme etkisi” olarak tanımlanmıştr. Turizmin, terörizme 6-9 } \\
\text { ḩfta sonra tepki gösterdiği de ayrıca belirlenmiştir. }\end{array}$ \\
\hline $\begin{array}{l}\text { Gartner ve } \\
\text { Shen (1992) }\end{array}$ & $\begin{array}{l}1989 \text { yılındaki Tiananmen Meydanı çatışmasının dünya çapında yankı uyandırması sonucunda, turizmin yeni } \\
\text { gelişmekte olduğu Çin'i örnek olay kapsamında incelemiştir. Pekin'deki otel doluluk oranları \%30'un altına } \\
\text { düşmüş, } 300 \text { grup (yaklaşık } 11.500 \text { kişi) seyahat planlarını iptal etmiş ve turizm gelirleri 1989'da } 430 \text { milyon } \\
\text { dolar azalmıştır. }\end{array}$ \\
\hline $\begin{array}{l}\text { Gu ve } \\
\text { Martin (1992) }\end{array}$ & $\begin{array}{l}\text { Orlando Uluslararası Havaalanı'ndaki (OIA) gelen yolcu artşsı, ikincil veriler kullanılarak incelenmiştir. } 1986 \text { yılında } \\
\text { OIA'dan ayrılmış yolcular ileri aşamalı regresyon prosedürü ve diğer regresyon analizleri kullanılarak incelenmiştir. } \\
\text { Ortadoğu ve Avrupa'daki terörist kaçırma olaylarında meydana gelen artş̧ı, OIA'ya gelen yolcuların gelişlerini } \\
\text { olumlu bir şekilde etkilediğini ortaya çıkarmıştır. }\end{array}$ \\
\hline $\begin{array}{l}\text { Witt ve } \\
\text { More (1992) }\end{array}$ & $\begin{array}{l}1985 \text { yılında Kuzey İlanda'da (NI) ülkenin imajını turistik bir destinasyon olarak incelemek için } 8 \text { özel etkinliğe } \\
\text { katılan bireylerle kişisel mülakat yapıımıştr. Çalışma, özel etkinliklerin teşvik edilmesinin, NI’nin terörizm ve iç } \\
\text { karışıkıı̆ın neden olduğu olumsuz dış görünüşünü aşacak kadar ilgi yaratıp yaratmadığını incelemiştir. } \\
\text { Sonuçlar, NI'nin iç turizmi teşvik etmek için turizm pazarındaki payını arttrması gerektiğini göstermiştir. Ziyaretleri } \\
\text { artırmak için araştırmacılar, tanıtım faaliyetleriyle beraber yeni turizm ürünleri geliştirmeyi önermektedirler. }\end{array}$ \\
\hline Ryan (1993) & $\begin{array}{l}\text { Suç ve turizm ilişkisinin beş tip halinde sınıflandırıldığı bir tipoloji sunan kavramsal bir çalışmadır. Çalışma, terörizmi } \\
\text { ileri bir suç biçimi olarak sınıflandırmaktadır. }\end{array}$ \\
\hline Hall (1994) & $\begin{array}{l}\text { Turizm ile siyaset arasındaki ilişkiyi irdeleyen ve hükümetler tarafindan dünya çapında örnekler sunarak (ör. Fiji, } \\
\text { Avustralya, Net/Zelanda, Antarktika) ulusal politikaların uygulanması için turizmin kullanımına değinen kapsamlı bir } \\
\text { kitap çalışmasıdır. }\end{array}$ \\
\hline $\begin{array}{l}\text { Sönmez, } \\
\text { Backman ve } \\
\text { Allan (1994) }\end{array}$ & $\begin{array}{l}\text { Doğal felaketlere odaklanarak turizm krizlerini yöneten rehber bir kitap çalışmasıdır. "Afet" ve "kriz" kavramları } \\
\text { turizm endüstrisi kapsamında tanımlanmıştr. Eğer bir ülkenin güvenlik imajı zarar gördüyse (örneğin, Mısır, } \\
\text { Peru, İsrail), tekrarlanan terörist saldırılarının ülke için kriz durumu oluşturabileceğini belirtmektedir. }\end{array}$ \\
\hline Aziz (1995) & $\begin{array}{l}\text { Çalışmada turistlere karşı Mısır'da yapılan terör olayları tartşıımakta ve bu durum Mısır'daki yerel halk ve turistler } \\
\text { arasındaki sosyoekonomik uçuruma dayandırımaktadır. Değerlerin ve kültürlerin anlaşamaması ile sonuçlanan } \\
\text { gerilim turist saldırılarını açıklamak için kullanılmaktadır. Yerel halkın İslami gelenek ve kültürel değerleri ile } \\
\text { örtüşmeyen bazı turist davranışlarıyla yaşadığı gerilim (kıyafetleri; domuz eti yemeleri ve alkol tüketimi; kumar) } \\
\text { vurgulanmaktadır. }\end{array}$ \\
\hline Mansfeld (1995 ve 1996) & “Orta Doğu” faktörü baz alınarak savaş ve turizm arasındaki ilişki incelenmektedir. \\
\hline $\begin{array}{l}\text { Sharpley ve } \\
\text { Sharpley (1995) }\end{array}$ & $\begin{array}{l}\text { Bir askeri darbenin Gambiya'nın turizm endüstrisindeki yansımalarını incelenmektedir. Gambiya siyasi olarak } \\
\text { İngiltere'den bağımsızığııı kazandığı yıldan kansız geçen darbe yılına kadar istikrarlı bir yol çizmekteydi. Darbeyle } \\
\text { beraber, turizme yönelik geliştirilen çeşitli propagandalar gelen turist sayıının 5.000'den 300'e düşürmüş, 2.000'in } \\
\text { üzerinde iş kaybının yaşanmasına neden olmuş, } 8 \text { otel kapanmış ve ekonomik ve sosyal koşullar bozulmuştur. }\end{array}$ \\
\hline Wahab (1995) & $\begin{array}{l}\text { Kavramsal olan bu çalışma, Mısır’ın turistlere karşı düzenlediği terör saldıılarını, "modernitenin yolsuzluğuna } \\
\text { direnmek için klasik İslami toplumsal kuralları yeniden canlandırmaya çalışan gruplar" olarak değerlendirmektedir. } \\
\text { Yazar, muhafazakâr yerlilerin, ulusal kültür, gelenek ve dini inançlara karşı bir tehdit olarak algıladıkları şeyleri } \\
\text { önlemek için şiddetli bir eylemde bulunma düşüncesinde olduklarına inanmaktadır; aşııı durumlarda, kızgınlık } \\
\text { kendini terörizmle ortaya koymaktadır. }\end{array}$ \\
\hline Bar-On (1996) & $\begin{array}{l}\text { Çalışma seyahat ve turizm eğilimleri, terör saldırıları, savaşlar ve sert siyasi sorunlara yöneliktir ve Mısır, İsrail, İspanya } \\
\text { e Türkiye'deki turistik faaliyetlerin karmaşık bir incelemesini sunmaktadır. }\end{array}$ \\
\hline $\begin{array}{l}\text { Hall ve } \\
\text { O’Sullivan (1996) }\end{array}$ & $\begin{array}{l}\text { Çalışmada turizm, siyasi istikrar ve şiddet arasındaki bağlantı tartışılmaktadır. Yazarlar çalışmada siyasi istikrarsızlığın } \\
\text { boyutlarını (uluslararası savaşlar, iç savaşlar, darbeler, terörizm, isyan/siyasi protesto/toplumsal huzursuzluk, grev) } \\
\text { sunmaktadırlar ve siyasi kargaşanın Çin ve Hırvatistan’ın turizm endüstrileri üzerindeki etkilerine odaklanmaktadır. } \\
\text { Politik istikrarsızık/şiddet yaşayan ulusların bir listesi de çalışmada yer almaktadır. }\end{array}$ \\
\hline
\end{tabular}


Tablo 2. Turizm ile Terörizm veya Siyasal İstikrarsızlık İlişkisine Odaklanan Araştırmalar (Devam)

\begin{tabular}{|c|c|}
\hline Kaynak & Konu / Başlıca Bulgular / Sonuçlar \\
\hline Mihalic (1996) & $\begin{array}{l}\text { Savaşın Slovenya'daki turizm sektörüne olan etkisi örnek olay kapsamında incelenmiştir. Yugoslavya'nın turizm } \\
\text { faaliyeti, Balkan savaşı (Slovenya, Hırvatistan, Bosna-Hersek) nedeniyle aniden kesilmiştir. Yugoslavya'daki tur } \\
\text { operatörleri 1991'de } 1 \text { milyondan fazla turist kaybetmiştir. }\end{array}$ \\
\hline Pitts (1996) & $\begin{array}{l}\text { Çalışmada ,NAFTA'ya tepki olarak Meksika hükümetine karşı ayaklanan Ezercito Zapatista Kurtuluş Ordusu } \\
\text { (EZLN) silahlı isyanının örnek olay incelemesi yapılmıştır. Yazar, otel sahipleri, hükümette yer alan turizm yetkilileri, } \\
\text { turizm tedarikçileri ve turizm bakanı olmak üzere toplamda } 27 \text { kişiyle görüşme yapmıştır. Chiapas'daki San Cristobal } \\
\text { bölgesinde, uluslararası/yerli turizmde ciddi düşüşler yaşandığı ortaya çıkarılmıştır. Yazar San Cristobal'da kargaşa y } \\
\text { a da savaş turistleri (eylemle ilgilenen) ve gazeteciler, araştırmacılar ve insan hakları aktivistleri olmak üzere iki farklı } \\
\text { turist türünü ortaya koymuştur. Chiapas, etnik turizm ürününden, çatışma deneyimi ve "siyasi şiddet heyecanı" } \\
\text { sunan turizm türüne dönüştürüldüg̈ü çalışmada sunulan bir diğer sonuçtur. }\end{array}$ \\
\hline $\begin{array}{l}\text { Sönmez ve } \\
\text { Graefe (1996) }\end{array}$ & $\begin{array}{l}\text { ABD’de uluslararası turistlerin on risk türü ile genel risk algıları arasındaki ilişkileri ve sekiz coğrafi bölge ile en iyi } \\
\text { yedi tatil bölgesinin oluşturduğu risk derecesinin ampirik çalışması yapılmıştı. Sonuçlar, terörizm, siyasi istikrarsızlık } \\
\text { ve memnuniyet risklerinin çoğunlukla Amerikalı turistlerin uluslararası seyahatleriyle ilişkili olduğunu ortaya } \\
\text { konulmuştur. Siyasi istikrarsızıı, memnuniyet ve fiziksel risklerin farklı coğrafi bölgelerle ilişkili olduğu ayrıca } \\
\text { saptanmıştr. }\end{array}$ \\
\hline Wahab (1996) & $\begin{array}{l}\text { Mısır’ın terörle mücadele konusunu ele alan çalışmada yazar Mısır polis teşkilatının ülkeyi ve turizmi korumak için } \\
\text { sıkı cezai önlemler üzerine kurulu terörle mücadele önlemlerini hayata geçirdiğini belirtmektedir. Savunmadan } \\
\text { önlemeye ve tepki vermekten olayları tahmin etmeye doğru değişen polis önlemleri Mısır turizm bakanı tarafindan } \\
\text { krizin üstesinden gelmek için uygulanmıştır. Yazar, kötü imajın yansıtılmasının üstesinden gelmenin tek yolunun, } \\
\text { uluslararası medyanın dikkatini çekmek için güçlü tanıtımlar yapmanın gerekliliğinin altını çizmektedir. Olumlu } \\
\text { tanıtımların yapılması için özel etkinliklerin başlatılması, uluslararası seyahat uzmanlarına ve basına eksiksiz bilgi } \\
\text { verilmesi ve turistlerin güvenli alanlarda tutulması gibi öneriler sunulmuştur. }\end{array}$ \\
\hline Wall (1996) & $\begin{array}{l}\text { Yazar, turist sayıları, ziyaretçilerin kökenleri, menşei ülkeye göre turizm gelirleri ve seyahat amacı bakımından Kuzey } \\
\text { İrlanda'yı İrlanda Cumhuriyeti ile karşılaştırmaktadır. Sonuç olarak görülmüştür ki Kuzey İrlanda'nın ziyaretçileri } \\
\text { İrlanda Cumhuriyeti ziyaretçilerine göre daha fazladır fakat daha az para harcayan ziyaretçi durumundadırlar. Çünkü } \\
\text { gelen kişiler çoğunlukla arkadaş/akrabalarını ziyaret etmek üzere gelmektedirler. Çalışma ayrıca Kuzey İrlanda } \\
\text { ziyaretçilerinin terör faaliyetlerden oldukça haberdar olduğunu ve temel nedenlerini anladıkları için daha az tehdit } \\
\text { altında hissettiklerini de ortaya çıkarmaktadır. }\end{array}$ \\
\hline $\begin{array}{l}\text { Siinmez ve } \\
\text { Graefe (1998) }\end{array}$ & $\begin{array}{l}\text { Uluslararası bazda kişilerin seyahat karar verme sürecinin ve terörizm tehdidinin önemli aşamalarının uluslararası } \\
\text { turizm tecrübesi, risk algılama seviyesi, uluslararası tutum, yaş, cinsiyet, eğitim, gelir ve hane halkı varlığı arasındaki } \\
\text { ilişkilerinin ampirik çalışması yapıımıştır. Bu bağlamda } 500 \text { yabancı turiste gönderilen bir posta anketi \% } 48 \text { oranında } \\
\text { cevaplanmış ve veriler çoklu ve basit regresyon kullanılarak analiz edilmiştir. Sonuç olarak, uluslararası turizm } \\
\text { tutumu, risk algılama seviyesi ve gelirin uluslararası bölge seçimini doğrudan etkilediği ancak turizm tecrübesinin } \\
\text { ve eğitiminin dolaylı etkiler olarak ortaya çıktığı bulunmuştur. }\end{array}$ \\
\hline
\end{tabular}

Terörizm, siyasi mücadele ya da bölgesel savaşı deneyimleyen bölgelerin yeni örnek olay olarak incelenmeleri etkili ve etkisiz yönetim ve iyileştirme çabalarını belirlemede son derece yararlı olmaktadır. Hiç kuşkusuz, başkalarının deneyimleri, başarıları ve başarısızlıkları, benzer krizlerin üstesinden gelebilmek açısından gerçekçi çözümlere ihtiyaç duyan turizm yetkilileri ve yöneticileri için çok değerli bir bilgi kaynağı olmaktadır. Şüphesiz ki endüstride, kapsamlı bir terör kriz yönetimine ihtiyaç duymaktadır. Etkili bir kriz yönetimi ve piyasa iyileştirme çözümlerine ilişkin diğer bölgelerin çabalarını inceleyerek (özellikle de tam iyileşme amacı izlendiğinde) derlemek faydalı bir unsur olabilmektedir. Çün- kü derlenen çözümler, gerektiğinde diğer bölgelerin belirli ihtiyaç ve koşullarına uygun olacak şekilde uyarlanabilir. Siyasi şiddetin bölge imajını nasıl etkilediğini, kitle iletişim araçlarının bölge imajının gelişimine nasıl katkıda bulunduğunu ve olumsuz bir olaydan sonra, özellikle de medya incelemesiyle beraber imajın nasıl onar1labileceğini daha iyi anlamak için araştırmalara ihtiyaç duyulmaktadır. Bölge imajı üzerinde geniş bir alanyazın taraması bulunsa da, bu konulara pek önem verildiği söylenememektedir. Bir diğer endişe ise, her ne kadar yanıt vermek zor olsa da, özellikle bir bölge olarak bir ülkenin turizm imajı ve muhtemel ekonomik kapasitesi tehlikeye girdiğinde terör olaylarının medya tarafından kullanılmasının nasıl engelleneceğidir. 
Çalışmalarda, turist kararların bir birleşimi olarak risk unsuru sınırlı bir şekilde ele alınmıştır (Cook ve Fesenmaier 1992; Urn ve Crompton 1992; Siinmez ve Graefe 1996, 1997). Potansiyel turistler genellikle medyanın uluslararası siyasi şiddetine maruz kalmaktadırlar. Terörizmle-turizm arasındaki istikrarsız ilişki, teröristler tarafından hedef olma ihtimallerini örtmek gibi bir davranış içerisinde olan medya tarafından büyütülmektedir. Sonuç olarak, algılanan risk, bölgelere yönelik tutumların şekillendirilmesinde gerçeğe daha ağır basmaktadır. Seyahat riskinin, gerçek ile algılanan risk ve bölge imajı ile turist tutumları bakımından incelenmesi daha faydalı olacaktır. Çünkü bölge, pazarlayanların algı, tutumları ve endişelerini gidermek için reklam stratejileri tasarlamak ve olumsuz durumu değiştirmek ve olumlu algıları güçlendirmek durumundadir.

Son olarak, tarafsız seyahat bilgilerini yaymak için (Sharpley ve Sharpley 1995 tarafından önerilen şekilde) bağımsız ve uluslararası bir organizasyon yaratmanın fizibilitesi ve lojistiği araştırılmalıdır. Böyle bir oluşumun olması, siyasi şiddetten etkilenmeyen bir bölgenin turizm endüstrisine ciddi hasar vermesine engel olabilir, ancak diğer ülkeler tarafından (bilinçli olarak, siyasi sebeplerden ya da aşırı tepki olarak) tehlikeli bir durum olarak ilan edilebilir. Ayrıca, ilgili ve güncel konuların gelecek çalışmalardan ortaya çikması muhtemeldir.

\section{KAYNAKÇA}

Abu Fadil M. (1992). Special Feature: The Terrorists won't Go Away, The Middle East, 217: 15-18.

Atkinson S. E., Sandier T. ve Tschirhart J. (1987). Terrorism in a Bargaining Framework, The Journal of Law and Economics, 30 (1): 1-21.

Aziz H. (1995). Understanding Terrorist Attacks on Tourists in Egypt, Tourism Management, 16 (2): 91-95.

Bach S. A. (1996). Tourist-Related Crime and the Hotel Industry: A Review of the Literature and Related Materials. İçinde: A. Pizam ve Y. Mansfeld (Editörler) Tourism, Crime and International Security Issues (ss. 281-296). New York: Wiley.

Bar-On R. R. (1996). Measuring the Effects on Tourism of Violence and of Promotion Following Violent Acts. İçinde: A. Pizam ve Y. Mansfeld (Editörler) Tourism, Crime and International Security Issues (ss. 159-174). New York: Wiley.
Bramwell B. ve Rawding L. (1996). Tourism Marketing Images of Industrial Cities, Annals of Tourism Research, 23 (1): 201-221.

Brookfield H. C. (1969). On the Environment as Perceived. İçinde: C. Board, P. Haggett, R. Chorley, ve D. Stoddert (Editörler) Progress in Geography (s. 68). Londra: Edward Arnold.

Bloom J. (1996). A South African Perspective of the Effects of Crime and Violence on the Tourism Industry. İçinde: A. Pizam ve Y. Mansfeld (Editörler) Tourism, Crime and International Security Issues (ss. 91-102). New York: Wiley.

Brady J. ve Widdows R. (1988). The Impact of World Events on Travel to Europe During the Summer of 1986, Journal of Travel Research, 26 (3): 8-10.

Buckley P. J. ve Klemm M. (1993). The Decline of Tourism in Northern Ireland: The Causes, Tourism Management, 14 (3):184-194.

Butler R. W. (1990). The Influence of the Media in Shaping International Tourist Patterns, Tourism Recreation Research, 15 (2): 46-53.

Chandler J. G. (1991). How Safe Are Our Airports?, Travel and Leisure, 21 (5):94-100.

Chesney-Lind M., ve Lind I. (1986). Visitors as Victims. Crimes Against Tourists in Hawaii, Annals of Tourism Research, 13(2): 167-191.

Chomsky N., ve Herman E. S. (1979). The Washington Connection and Third World Fascism. Kanada: Black Rose Books.

Chon K. S. (1991). Tourism Destination Image Modification Process: Marketing Implications, Tourism Management, 12 (1): 68-72.

Cohen E. (1996). Touting Tourists in Thailand: Tourist-Oriented Crime and Social Structure. İçinde: A. Pizam and Y. Mansfeld (Editörler) Tourism. Crime and International Securitv Issues (ss. 77-190). New York: Wiley.

Conant J. S., Clark T., Burnett J. J. ve Zank G. (1988). Terrorism and Travel: Managing the Unmanageable, Journal of Travel Research, 26 (4): 16-20.

Cook W. J. (1990). The Effect of Terrorism on Executives' Willingness to Travel Internationallv (Basılmamış Doktora Tezi). New York: The City University of New York.

Cook R. L. ve McClearv K. W. (1983) Redefining Vacation Distances in Consumer Minds, Journal of Travel Research, 22 (3): 1-34.

Crompton J. L. (1992). Structure of Vacation Destination Choice Sets, Annals of Tourism Research, 19 (3): 420-434.

Crompton J. L. (1979). An Assessment of the Image of Mexico as a Vacation Destination and the Influence of Geographical Location Upon that Image, Journal of Trave Research, 17(4): 18-23.

D'Amore L. J. ve Anuza T. E. (1986). International Terrorism: Implications and Challenge for Global Tourism, Business Quarterly, 4: 20-29.

Dann G. M. S. (1993). Tourists' Images of a Destination-an Alternative Analysis. İçinde: D. R. Fesenmaier, J. T. O'Leary, ve M. Uysal (Editörler) Recent Advances in Tourism Marketing Research (ss. 41-55). New York: The Haworth Press. 
Demos E. (1992). Concern for Safety: A Potential Problem in the Tourist Industry, Journal of Travel and Tourism Marketing, 1 (1): 81-88.

Dichter E. (1985). What's in an Image, The Journal of Consumer Marketing, 2 (1): 75-81.

Diller F. ve Scofidio D. (1994). Back to the Front: Tourisms of War. Basse-Normandie: FRAC.

Edgell Sr. D. L. (1990). International Tourism Policy. New York: Van Nostrand Reinhold.

Echtner C. M. ve Ritchie J. R. B. (1991). The Measurement of Destination Image: An Empirical Assessment, Journal of Travel Research, 31(4): 3-13.

Ehemann J. (1977). What Kind of Place is Ireland: An Image Perceived through the American Media, Journal of Travel Research, 16 (2): 28-30.

Enders W. ve Sandler T. (1991). Causality between Transnational Terrorism and Tourism: The Case of Spain, Studies in Conflict \& Terrorism, 14 (1): 49-58.

Enders W., Sandler T. ve Parise G. F. (1992). An Econometric Analysis of the Impact of Terrorism on Tourism, Kyklos, 45 (4): 531-554.

Englander D. W. (1991). What You Need to Know to Fly Safely Now, Money, 29 (3): 156.

Fedarko K. (1993). Holidays in Hell, Time, 23: 50-51.

Fletcher M. (1993). Egypt: Is This the Time to Visit?, Travel and Leisure, 23 (6): 60-64.

Galtung J. ve Ruge M. H. (1965). The Structure of Foreign News: The presentation of the Congo, Cuba and Cyprus crises in four Norwegian newspapers, Journal of Peace Research, 2 (1): 64-80.

Gartner W. C. (1993). Image Formation Process. In Recent Advances. İçinde: D. R. Fesenmaier, J. T. O'Leary ve M. Uysal (Editörler) Tourism Marketing Research (ss. 191215). New York: The Haworth Press.

Gartner W. C. (1989). Tourism Image: Attribute Measurement of State Tourism Products Using Multidimensional Scaling Techniques, Journal of Travel Research, 28 (2): 1620.

Gartner W. C., ve Shen J. 1992 The Impact of Tiananmen Square on China's Tourism Image, Journal of Travel Research, 30:47-52.

Goszczynska M., Tyszka T. ve Slavic P. (1991). Risk Perception in Poland: A Comparison with three other countries, Journal of Behavioral Decision Making, 4 (3): 179-193.

Gu Z. ve Martin T. L. (1992). Terrorism, Seasonality, and International Air Tourist Arrivals in Central Florida: An Empirical Analysis, Journal of Travel and Tourism Marketing, 1 (1): 3- 15.

Gunn C. (1972). Vacationscape. Austin TX: The University of Texas, Bureau of Business Research.

Hagerty B. (1993). Egypt Struggles to Reassure Tourists, Targets in a Wave of Terrorist Activity, Wall Street Journal, 1: 51.

Hall C. M. (1994). Tourism and Politics: Policy, Power and Place. New York: Wiley.

Hall C. M. ve O'Sullivan V. (1996). Tourism, Political Stability and Violence. İçinde: A. Pizam ve Y. Mansfeld (Editörler) Tourism, Crime and International Security Issues (ss. 105-121). New York: Wiley.
Hartz C. (1989). Business Executives as International Terrorist Targets. İçinde: J. R. Buckwalter (Editör) International Terrorism: The Decade Ahead (ss. 21-28). Chicago: The University of Illinois at Chicago. Office of International Criminal Justice.

Hollier R. (1991). Conflict in the Gulf: Response of the Tourism Industry, Tourism Management, 12 (1): 2-4.

Hollinger R. (1995). Crime and Florida's Tourists. İçinde: Security and Risks in Travel and Tourism, Proceedings of the Talk at the Top Conference (ss.183-215). Ostersund: MidSweden University.

Hurley J. A. (1988) The Hotels of Rome: Meeting the Marketing Challenge of Terrorism, The Cornell Quarterly, 29 (1): 71-79.

Jenkins B. (1987) The Future Course of International Terrorism. İçinde: A. Kurz (Editör) Contemporary Trends in World Terrorism (ss. 150-159). New York: Praeger.

Jenkins B. (1988). Future Trends in International Terrorism. İcinde: R. 0. Slater ve M. Stohl (Editörler) Current Perspectives on International Terrorism (ss. 246-266). London: Macmillan.

Karber P. A. (1971). Terrorism as Social Protest. (Basılmamış Çalışma).

Kemmer C. (1995). Resident and Visitor Safety and Security in Waikiki. İçinde: Security and Risks in Travel and Tourism, Proceedings of the Talk at the Top Conference, (ss. 75-83). Ostersund: Mid-Sweden University.

Lankford S. V. (1996). Crime and Tourism: A Study of Perceptions in the Pacific Northwest. İçinde: A. Pizam ve Y. Mansfeld (Editörler) Tourism, Crime and International Security Issues (ss. 51-58). New York: Wiley.

Lea J. P. (1996). Tourism, Tealpolitik and Development in the South Pacific. İçinde: A. Pizam ve Y. Mansfeld (Editörler) Tourism, Crime and International Security Issues (ss. 123-142). New York: Wiley.

LeBruto S. M. (1996). Legal Aspects of Tourism and Violence. İçinde: A. Pizam ve Y. Mansfeld (Editörler) Tourism, Crime and International Security Issues (ss. 297-310). New York: Wiley.

Lehrman C. K. (1986). When Fact and Fantasy Collide: Crisis Management in the Travel Industry, Public Relations Journal, 42: 25-28.

Mansfeld Y. (1992). From Motivation to Actual Travel, Annals of Tourism Research, 19 (3): 399-419.

Mansfeld Y. (1996). Wars, Tourism and the "Middle East" Factor. İçinde: A. Pizam ve Y. Mansfeld (Editörler) Tourism, Crime and International Security Issues (ss. 265-278). New York: Wiley.

Mansfeld Y. ve Kliot N. (1996). The Tourism Industry in the Partitioned Island of Cyprus. İçinde: A. Pizam ve Y. Mansfeld (Editörler) Tourism, Crime and International Security Issues, (ss. 187-202). New York: Wiley.

Mayo E. J. (1973). Regional Images and Regional Travel Behavior. İçinde: The Travel Research Association Fourth Annual Conference Proceedings (ss. 211-218). Boulder: The University of Colorado Business Division.

Mechitov A. I. ve Rebrik S. B. (1990). Studies of Risk and Safety Perception in USSR. İçinde: K. Borcherding, 0. I. Larichev ve D. M. Messick (Editörler) Contemporary Issues in Decision Making (ss. 261-270). Amsterdam: Elsevier. 
Mihalic T. (1996). Tourism and Warfare. The Case of Slovenia. İçinde: A. Pizam ve Y. Mansfeld (Editörler) Tourism, Crime and International Security Issues (ss. 231-246). New York: Wiley.

Murphy J. F. (1989). State Support of International Terrorism. San Francisco: Westview Press.

Ni Aolain F. (1996). Where Hope and History RhymeProspects for Peace in Northern Ireland?, Journal of International Affairs, 50 (1): 63-89.

Norton G. (1987). Tourism and International Terrorism. The World Today, 43: 30-33.

O'Neill M. A. ve Fitz F. (1996). Northern Ireland Tourism: What Chance Now?, Tourism Management, 17 (3): 161-163.

Pelton R. Y. ve Aral C. (1995). The World's Most Dangerous Places. Redondo Beach CA: Fielding Worldwide.

Pitts W. J. (1996). Uprising in Chiapas, Mexico: Zapata Lives: Tourism Falters. İçinde: A. Pizam ve Y. Mansfeld (Editörler) Tourism, Crime and International Security Issues (ss. 215-227). New York: Wiley.

Pizam A. (1982). Tourism and Crime: Is There a Relationship? Journal of Travel Research, 20 (3): 7-10.

Pizam A. ve Mansfeld Y. (1996). Tourism, Crime and International Security Issues. New York: Wiley.

Poland J. M. (1988). Understanding Terrorism. Englewood Cliffs NJ: Prentice-Hall.

Prideaux B. (1996). The Tourism Crime Cycle: A Beach Destination Case Study. İçinde: A. Pizam ve Y. Mansfeld (Editörler) Tourism, Crime and International Security Issues (ss. 59-75). New York: Wiley.

Ranstorp M. (1996). Terrorism in the Name of Religion, Journal of International Affairs, 50 (1): 4162.

Reeves R. (1987). Thoughts on Terrorism, Travel and Leisure, 17: 64-66.

Richter L. K. (1980). The Political Uses of Tourism: A Philippine Case Study, The Journal of Developing Areas, 14 (2): 237-257.

Richter L. K. ve Waugh Jr W. L. (1983). Tourism Politics and Political Science: A Case of Not So Benign Neglect, $A n$ nals of Tourism Research, 10 (3): 313-315.

Richter L. K. ve Waugh Jr W. L. (1986). Terrorism and Tourism as Logical Companions, Tourism Management, 7 (4): 230-238.

Roehl W. S. and Fesenmaier D. R. (1992). Risk Perceptions and Pleasure Travel: An Exploratory Analysis, Journal of Travel Research, 30 (4): 17-26.

Ryan C. (1993). Crime, Violence, Terrorism and Tourism: An Accidental or Intrinsic Relationship?, Tourism Management, 14 (3): 173-183.

Ryan C. ve Kinder R. (1996). The Deviant Tourist and the Crimogenic Place: the Case of the Tourist and the New England Prostitute. İçinde: A. Pizam ve Y. Mansfeld (Editörler) Tourism, Crime and International Security Issues (ss. 23-26). New York: Wiley.

Schiebler S. A., Crotts J. C. ve Hollinger R. C. (1996). Florida Tourists' Vulnerability to Crime. İçinde: A. Pizam ve Y. Mansfeld (Editörler) Tourism, Crime and International Security Issues (ss. 37-50). New York: Wiley.

Schlagheck D. M. (1988). International Terrorism. Lexington MA: Lexington Books.
Schwartz R. D. (1991). Travelers under Fire: Tourists in the Tibetan Uprising, Annals of Tourism Research, 18 (4): 588604.

Scott R. (1988). Managing Crisis in Tourism: A Case Study of Fiji, Travel and Tourism Analyst (6): 57-71.

Sharpley R. ve Sharpley J. (1995). Travel Advice: Security or Politics? İçinde: Security and Risks in Travel and Tourism, Proceedings of the Talk at the Top Conference (ss. 168182). Ostersund: Mid-Sweden University.

Skolnik R. (1991). US Travel and Tourism Today. Public Relations Journal 47: 16-2 1.

Smith V. (1996). War and its Tourist Attractions. İçinde: A. Pizam ve Y. Mansfeld (Editörler) Tourism, Crime and International Security Issues (ss. 247-264). New York: Wiley.

Sonmez S. F., Backman S. J. ve Allen L. R. (1994). Managing Tourism Crises: A Guidebook. Clemson, SC: Clemson University.

Sonmez S. F. ve Graefe A. R. (1998). International Vacation Decisions and Terrorism Risk, Annals of Tourism Research, 25 (1): 112-144.

Sonmez S. F. ve Graefe A. R. (1996). Risk Perceptions of US International Vacation Travelers. İçinde: Proceedings of the 27th Annual Travel and Tourism Research Association (ss. 192-200). Las Vegas, Nevada. Boulder: The University of Colorado Business Division.

Tarlow P. ve Muehsam M. (1996). Theoretical Aspects of Crime as They Impact the Tourism Industry. İçinde: A. Pizam ve Y. Mansfeld (Editörler) Tourism, Crime and International Security Issues (ss. 11-22). New York: Wiley.

Teye V. B. (1986). Liberation Wars and Tourism Development in Africa: The Case of Zambia, Annals of Tourism Research, 13 (4): 589-608.

Teye V. B. (1988). Coups d'Etat and African Tourism: A Study of Ghana, Annals of Tourism Research, 15 (3): 329-56

The Economist. (1986a). East, West, Home's Best. The Economist, 300: 28 .

The Economist. (1986b). Europe Suffers From American Stayaways, The Economist, 299: 63-64.

The Economist. (1990). Ambushing the Peace Bus. The Economist, 314: 41-42.

Tiegen K. H. Brun W. ve Slavic P. (1988). Societal Risks as Seen by a Norwegian Public, Journal of Behavioral Decision Making, 1 (2): 111-130.

Tremblay P. (1989). Pooling International Tourism in Western Europe, Annals of Tourism Research, 16 (4): 477-491.

Urn, S. ve Crompton J. L. (1992). The Roles of Perceived Inhibitors and Facilitators in Pleasure Travel Destination Decisions, Journal of Travel Research, 30 (3): 18-25.

US House of Representatives. (1991). The Impact of the Threat of Terrorism and the Recession on the Travel and Tourism Industry. Serial No. 102-6. Washington DC: US Government Printing Office.

US Department of State. (1997). Patterns of Global Terrorism: 1996. Washington DC: US Department of State.

US Department of State. (1996). Patterns of Global Terrorism: 1995. Washington DC: US Department of State.

Vanraaij W. F. ve Francken D. A. (1984). Vacation Decisions, Activities, and Satisfactions, Annals of Tourism Research, 11 (1): 101-1 12. 
Wahab S. (1996). Tourism and Terrorism: Synthesis of the Problem with Emphasis on Egypt. İçinde: A. Pizam ve Y. Mansfeld (Editörler) Tourism, Crime and International Security Issues (ss. 175-186). New York: Wiley.

Wahab S. (1995). Terrorism: A Challenge to Tourism. İçinde: Security and Risks in Travel and Tourism, Proceedings of the Talk at the Top Conference (ss. 84-108). Ostersund: Mid-Sweden University.

Wall G. (1996). Terrorism and Tourism: An Overview and an Irish Example. İçinde: A. Pizam ve Y. Mansfeld (Editörler) Tourism,Crime and International Security Issues (ss. 143-158). New York: Wiley.

Waugh Jr. W. L. (1990). Terrorism and Emergency Management. New York: Marcel Dekker.
Weimann G. ve Winn C. (1994). The Theater of Terror: Mass Media and International Terrorism. White Plains NY: Longman.

Wieviorka M. (1994). The Making of Terrorism. Chicago: University of Chicago Press.

Witt S. F. ve Moore S. A. (1992). Promoting Tourism in the Face of Terrorism: The Role of Special Events in Northern Ireland, Journal of International Consumer Marketing, 4 (3): 63-75.

Woodside A. G. ve Lysonski A. (1989). A General Model of Traveler Destination Choice, Journal of Travel Research, 27 (4): 8-14.

World Tourism Organization. (1991). Impact of the Gulf Crisis on International Tourism. World Tourism Organization Special Report. Madrid Spain: WTO.
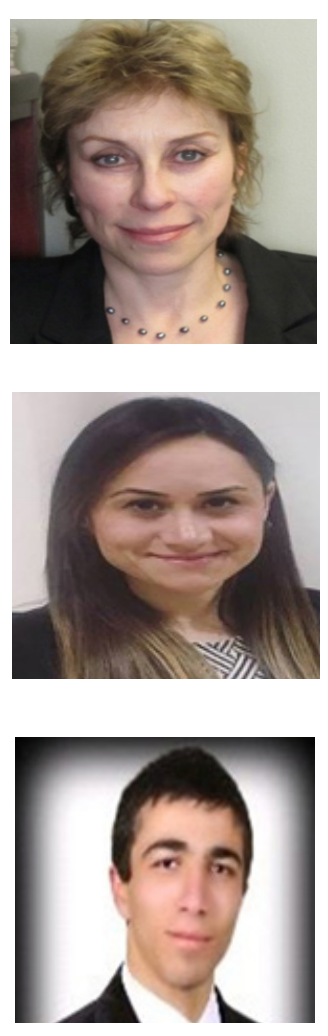

\section{Sevil F. SÖNMEZ}

Halen Central Florida Üniversitesi Rosen College of Hospitality Management'da görev yapmaktadır. Disiplinler arası çalışmaktadır. Önceki çalışmaları, risk (terörizm, siyasi istikrarsızlık, krizler) ve turizm üzerine yoğunlaşmaktayken şimdilerde mesleki/boş zaman hareketliliğinin sağlık sonuçları ve turizm/konaklama endüstrisinde iş sağı̆̆ı konuları üzerinde çalışmalarını devam ettirmektedir. Çalışmaları önde gelen turizm ve sağlık dergilerinde yayımlanmış, ayrıca üç kitabın editörlüğünü yapmıştır.

\section{Ayşegül ACAR}

Boğaziçi Üniversitesi Uygulamalı Bilimler Yüksekokulu'ndan 2014 yılında mezun oldu. Yüksek lisans derecesini İstanbul Üniversitesi Sosyal Bilimler Enstitüsü Turizm İşletmeciliği anabilim dalından (2016) almış olup, doktora derecesine de İstanbul Üniversitesi Turizm ișletmeciliğinde devam etmektedir. Karabük Üniversitesinde çalışmaya başladı (2015). Halen Karabük Üniversitesi Safranbolu Turizm Fakültesi Turizm İşletmeciliği Bölümünde Araştırma Görevlisi olarak çalışmaktadır.

\section{Ozan ATSIZ}

Anadolu Üniversitesi Turizm ve Otel İşletmeciliği Yüksekokulu'ndan 2014 yılında mezun oldu. Yüksek lisans derecesini İstanbul Üniversitesi Turizm İșletmeciliği anabilim dalından (2016) almış olup, doktora derecesine de İstanbul Üniversitesi Turizm İşletmeciliğinde devam etmektedir. İstanbul Üniversitesi'nde çalışmaya başladı (2015). Halen İstanbul Üniversitesi İktisat Fakültesi'nde Araştırma Görevlisi olarak çalışmaktadır. 